\title{
WestVirginiaUniversity
}

THE RESEARCH REPOSITORY @ WVU

Graduate Theses, Dissertations, and Problem Reports

2005

\section{Crisis manager of the American Revolution: Henry Laurens}

Jeffrey R. Gudzune

West Virginia University

Follow this and additional works at: https://researchrepository.wvu.edu/etd

\section{Recommended Citation}

Gudzune, Jeffrey R., "Crisis manager of the American Revolution: Henry Laurens" (2005). Graduate Theses, Dissertations, and Problem Reports. 773.

https://researchrepository.wvu.edu/etd/773

This Thesis is protected by copyright and/or related rights. It has been brought to you by the The Research Repository @ WVU with permission from the rights-holder(s). You are free to use this Thesis in any way that is permitted by the copyright and related rights legislation that applies to your use. For other uses you must obtain permission from the rights-holder(s) directly, unless additional rights are indicated by a Creative Commons license in the record and/ or on the work itself. This Thesis has been accepted for inclusion in WVU Graduate Theses, Dissertations, and Problem Reports collection by an authorized administrator of The Research Repository @ WVU. For more information, please contact researchrepository@mail.wvu.edu. 
Crisis Manager of the American Revolution: Henry Laurens

\author{
Jeffrey R Gudzune
}

\author{
Thesis submitted to the \\ Eberly College of Arts and Sciences \\ at West Virginia University \\ in partial fulfillment of the requirements \\ for the degree of
}

Master of Arts

in

American History

\author{
Mary Lou Lustig, Ph.D. \\ Kenneth Fones-Wolf, Ph.D. \\ John Super, Ph.D. \\ Department of History
}

Morgantown, West Virginia

2005

Keywords: Henry Laurens, Continental Congress, American Revolution Copyright 2005 Jeffrey R Gudzune 


\title{
ABSTRACT \\ Crisis Manager of the American Revolution: Henry Laurens
}

\author{
Jeffrey R Gudzune
}

\begin{abstract}
As President of the Continental Congress, Henry Laurens was a firm leader amid a time of national emergency. When a dispute within the Continental Army threatened both the continuation of General Washington's command and the American alliance with France, Laurens went beyond his limited sphere of political authority to settle the matter. When a peace commission from England arrived in the United States to begin discussing terms for an end to the hostilities, Laurens found himself in an increasingly difficult diplomatic situation. While wrestling with the question of whether or not to accept the British offer, Laurens was also forced to hold the tenuous union of thirteen sovereign states together amid internal disputes, some of which had spilled over into the national government. Throughout his term, Laurens stood out as an advocate for national unification against the British and contributed an essential service to the American Revolution.
\end{abstract}




\section{Table of Contents}

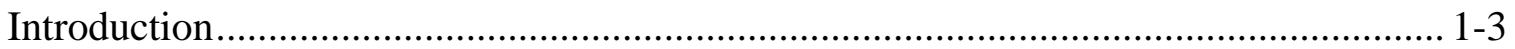

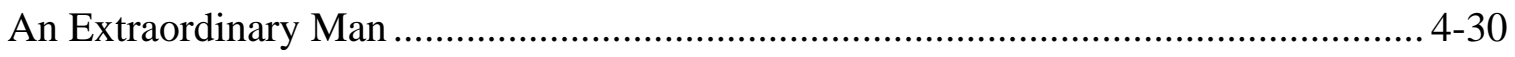

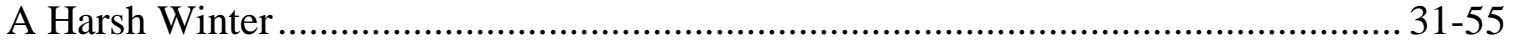

Atrophy and the French Alliance ...................................................................... 56-78

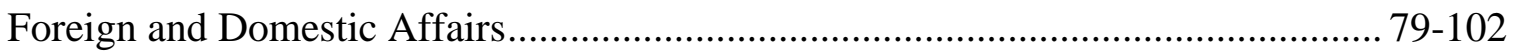

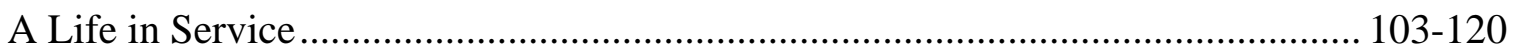

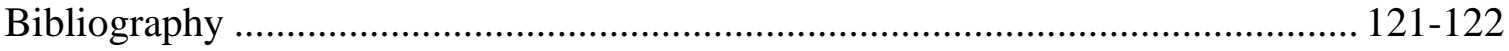




\section{$\underline{\text { Introduction }}$}

Henry Laurens did not seek a revolution, nor did he ask to be made President of the Continental Congress in 1777 . However, he was elected to the post and helped turn the tide of the American Revolution. When all seemed lost, when the Continental Army was out of funds and fracturing into personal and political chaos, when Congress itself seemed on the verge of atrophy, he took action when action was most needed. At this time, he emerged as a capable leader and crisis manager. Though a stranger to the Continental Congress, Laurens distinguished himself as America’s most powerful advocate during the financial and interpersonal conflicts that faced the young confederation throughout the year 1777. Henry Laurens was effective as a political leader, diplomat, and crisis manager during one of the most crucial years of the American Revolution, 1777-1778.

Henry Laurens' contribution to the cause of American independence cannot be underestimated. As President of the Continental Congress, Laurens led the American Confederation from November of 1777 until his resignation in December of 1778 . He guided the agenda of the Continental Congress and served as a conduit through which their deliberations reached the fledging nation. Though he was wary of the dangers inherent in a war with Great Britain, Henry Laurens embraced the task to which he was elected. His most significant contribution to the American Revolution was to stand behind General George Washington amid a controversy which grew from a dispute between Washington and General Thomas Conway. What began as a personal conflict between two generals soon grew to threaten the stability of the Continental Army and posed a danger to the alliance with France. Laurens advocated unity within the Congress 
at a time when delegations were drifting away from their national responsibilities. To deal with these and other problems during his term in office, Laurens drew on the experiences garnered in his early life in the mercantile industry, as well as his political background in the affairs of South Carolina.

While Henry Laurens' service to the cause of independence is well documented, few historians have gone into detail regarding his political impact while serving as president of the Continental Congress or his later activities. The literature surrounding Laurens and his life do not do justice to the full effect that the man had on the American Revolution. In many books on the subject he is mentioned only in passing. Authors like John Ferling and Joseph Ellis mention Laurens as president of the Continental Congress and then as a prisoner in the Tower of London, but they stop short of outlining his contributions. The main biography of Henry Laurens, David Duncan Wallace's The Life of Henry Laurens (New York: Russell and Russell, 1915), provides the most vivid detail about the man and his motivations during one of the most tumultuous years of the American Revolution. In this now dated monograph, the author portrays a man of unquestionable abilities, but neglects a detailed account of his actions. While Wallace provides a thorough historical timeline he neglects the overall effect of Laurens' political decisions. The evidence is presented in Wallace's argument, but fails to draw the necessary conclusions based on Laurens’ actions.

Gregory Massey’s John Laurens and the American Revolution (Columbia: University of South Carolina Press, 2000) looks at Henry Laurens and his relationship with his oldest son. While this book serves as a biography of the younger Laurens, it also includes insight into Henry Laurens and the effect of his political decisions on his 
personal life. The decisions that shaped Laurens’ political legacy during his tenure as president of Congress were made only after careful reflection on the issues at hand. He did not easily arrive at these decisions as they concerned the future of a new nation.

Scholarship regarding Henry Laurens usually presents him as a mediator in the debates of the Continental Congress. His job was to chair the meetings of Congress, and nothing else. As an executive, his authority was ill defined. He most certainly did not possess the vast authority that George Washington would have when he became the first President under the Constitution of the United States. However, Laurens’ private and public correspondence indicates that he was far more than a chairman--he was an active leader who took his responsibilities seriously.

Using these sources, it is easy to examine the political development of Henry Laurens from South Carolina merchant into an active proponent of the American Revolution. He did not begin his service to the national government as a committed proponent of revolution. However, as British taxation began to affect his life, Laurens began to change his opinions. To fully understand the man and his motivations it is necessary to examine his early life in South Carolina and the events that surrounded his conversion. This analysis will be a political biography exploring Henry Laurens in the roles of political leader, crisis manager, and diplomat. It is evident from a detailed exploration of his personal and political correspondence that Henry Laurens gradually evolved into a revolutionary figure. There is no example of a specific event that caused his change in thought. Like his evolution into a prosperous merchant, Henry Laurens became a supporter of the American cause only after a series of events corrected the course of his development. 


\section{Chapter One: An Extraordinary Man}

Henry Laurens was born in Charles Town, South Carolina on March 6, 1724 to John and Esther Laurens. John Laurens was a prosperous saddler, who had built a successful business that generated a comfortable living for him and his family. His business efforts were so profitable that he was able to retire while still a relatively young man and devote the remainder of his life to public service as a church warden and fire master for Charles Town. ${ }^{1}$

When Henry reached the age of twenty, he was dispatched to London to begin learning the merchant trade under James Crokatt, a man who had already achieved a great deal of success before transferring his business to London from South Carolina. Laurens learned the intricacies of the mercantile industry under a most apt tutor. Henry excelled in a field where it is essential for an individual to not only be a capable accountant, but a skilled organizer. During his apprenticeship, Henry traveled widely with Crokatt’s shipments and communicated their safe arrival to his mentor. The business contacts he made were integral to his success in later years. ${ }^{2}$

Expectations do not always yield a positive result, as young Henry Laurens would find out after serving under Crokatt for three years. It was his hope and indeed his expectation to achieve a partnership with his mentor. Having both learned the details of the merchant trade and provided valuable service to Crokatt, Laurens felt that he was the perfect man for the task. ${ }^{3}$ However, no such partnership materialized and Laurens

\footnotetext{
1 David Duncan Wallace, The Life of Henry Laurens. (New York: Russell and Russell, 1915), 13.

2 Wallace, 15-16.

3 Henry Laurens to James Crokatt, July 14, 1747, The Papers of Henry Laurens, Volume One: September 11, 1746-October 31, 1755. Philip M Hamer, ed. 2 vols. (Columbia: University of South Carolina Press, 1968), 1: 28-29. Though Laurens would not openly aggrandize himself in front of his mentor, his service and dedication prove his desire to attain the partnership.
} 
returned to South Carolina in 1747, unsure of his future. Arriving in Charles Town, Henry learned that his father had died no more than four days before his ship arrived in port. This news devastated the young man, who was now thrust into the arduous task of serving as executor of his late father's will. Around this same time, several letters arrived from London outlining the long anticipated partnership between Henry Laurens and James Crokatt--the good news coincided with the most devastating event of his young life. $^{4}$

Writing to James Crokatt, Laurens confessed that he was "under great concern for" the loss of his father and lamented the fact that he had been unable to communicate with Crokatt. ${ }^{5}$ Working to fulfill his commitment to Crokatt while at the same time seeing that his father's will was properly executed proved to be a task that drained him emotionally as well as physically. In a letter to Richard Grubb, a partner to James Crokatt, Laurens said that since he was entrusted with the task of settling his father's affairs, he had "scarcely the time to attend my own." ${ }^{6}$ In a subsequent letter to Crokatt, Laurens confessed that he was exhausted from his endeavors, yet he was aware of his obligation to perform all his duties. This is the first glimpse at Henry Laurens the task master, a quality he would continue to possess throughout his life and one that would become essential in his service during the American Revolution. ${ }^{7}$

\footnotetext{
${ }^{4}$ HL to James Crokatt, June 3, 1747, Papers. Hamer, 1:3.

${ }^{5}$ Ibid, 1:3. Laurens was writing his mentor in regard to his lack of communication concerning the shipments which he accompanied to South Carolina. Not only was he responsible for assuring their safe arrival, but he was also vested with the task of distributing them to the various markets and securing payment. This was a difficult time for the young man, having not only to cope with the loss of his father, but the added stress of competing in the market economy.

${ }^{6}$ HL to Richard Grubb, June 23, 1747, Papers. Hamer, 1:8. In this letter, the first evidence of strain is visible as Henry Laurens comments on how he has fallen behind in the execution of his other responsibilities--namely his duties to Crokatt and his personal life.

${ }^{7}$ HL to James Crokatt, June 24, 1747, Papers. Hamer, 1:9-10. This was not the last time Laurens performed multiple tasks.
} 
Laurens hoped to have his father's estate settled so he could be in London by late April, 1748. In his letters, Laurens refers to "the old scheme,” or partnership, with Crokatt. ${ }^{8}$ However, his pressing duties as executor of his father's estate forced him to twice delay his departure from South Carolina. As a means of gaining revenue and to keep up with the demands of the merchant industry, Laurens established a small store in Charles Town. This business allowed him to remain in contact with prominent South Carolina merchants and prepared him to assume the desired partnership with Crokatt. Though Crokatt granted Laurens an extension to his April deadline, the former apprentice was unable to leave Charles Town until September 28, 1748. In London, a series of unfortunate miscommunications and accusations of malfeasance made by Crokatt towards Laurens forever destroyed any chance of a business relationship. ${ }^{9}$

After his futile trip to London, Henry returned to South Carolina in 1749 and established a partnership with George Austin--it would soon prove to be a more fortuitous turn of events. ${ }^{10}$ His return to South Carolina was the beginning of many business and public associations that would lead him to an active role in the politics of his colony.

The firm of Austin and Laurens was successful. They exported corn, rice, millet and indigo to British markets in London and throughout England, and then used the profits from these sales to import items into the colonial market. South Carolina was in the midst of a booming economy as a result of trade with Great Britain and her

\footnotetext{
${ }^{8}$ HL to Alexander Watson, August 25, 1747, Papers. Hamer, 1:48.

${ }^{9}$ HL to Elizabeth Laurens, December 16, 1748, Papers. Hamer, 1: 179. Laurens was accused of not honoring his previous commitment to Crokatt. However, he insisted that he acted in good faith.

${ }^{10}$ HL to Foster Cunliffe, January 20, 1749, Papers. Hamer, 1: 203. It is altogether fortunate that Laurens returned to South Carolina when he did and resolved to enter into a business relationship with Mr. Austin. Having already made numerous contacts throughout coastal North America, and having established himself in Charles Town, Laurens was now putting himself into a position of great importance.
} 
dominions. ${ }^{11}$ Though the British Navigation Acts demanded that the majority of the export items went to the homeland, some goods were also sold to the more northern colonies of America and to the West Indies. According to David Wallace, South Carolina was rapidly growing into an economic powerhouse in the mid eighteenth century. A new generation of independently wealthy merchants and planters was taking hold in the colony, and Henry Laurens was one of the leaders of South Carolina society. Failure of the British to properly enforce the Navigation Acts allowed colonial merchants to increase their profits. ${ }^{12}$

By the end of their first year in business, Austin and Laurens had established a successful import-export business. The major import items were sugar, stationary, food products, beer, and clothing. ${ }^{13}$ By 1751 , the firm imported indentured servants and black slaves, and advertising their services to the Charles Town community. Laurens became a major player in the slave trade, an evil that had become necessary as South Carolina expanded its export industry, which was based on its plantation industry. Laurens grew wealthy from the slave trade and other importers sought his advice. Though he would one day lament his involvement, he made his fortune in the slave trade. ${ }^{14}$ His business efforts made Henry Laurens one of the richest men of South Carolina.

While Laurens was a member of a successful partnership, he frequently made his own investments and side agreements with his fellow merchants, as he had done while apprenticed to James Crokatt. He sold rum, beer, animals skins, even imported marble

11 HL to Richard Farr, February, 18, 1749, Papers. Hamer, 1:212.

12 Wallace, 26-27.

13 Advertisement, October 2, 1749, Papers. Hamer, 1:240.

14 Advertisement, October 23, 1751, Papers. Hamer, 1:242. 
facades for fireplaces to personal friends. ${ }^{15}$ To say that Henry Laurens was a busy man would not begin to describe the effort with which he embraced his responsibilities as a merchant. Laurens was involved in every aspect of his profession, accounting, recordkeeping, communication, and networking with other merchants. He traveled throughout Britain in search of the goods to import to South Carolina. He did this not only while engaged in business for the firm of Austin and Laurens, but for his own private ventures. From his business records, it is clear that Laurens knew the location of every shipment and remained in constant communication with the ports receiving his merchandise. ${ }^{16}$

Despite the complicated method through which items from one continent were purchased by merchants on another, a long and involved process that relied on payments sent through several intermediaries, Henry Laurens settled his accounts on time. ${ }^{17}$ This demonstrates the keen organizational skills requisite in a member of the merchant class, skills that Henry Laurens possessed and employed with vigor throughout his career. These skills became equally important in the decades to follow as Laurens confronted the task of building a nation out of thirteen sovereignties.

Despite the strenuous pace with which he embraced his business efforts, Laurens began a family. On June 25, 1750, Henry Laurens married Eleanor Ball. ${ }^{18}$ With his business success, Laurens moved into a new social strata--one that coincided with South Carolina's rise to economic prominence. South Carolina society endeavored to copy that of London. The wealthy planter elite and the merchant class had, in a generation, risen to

\footnotetext{
15 Wallace, 47.

16 HL to William Whaley, May 12, 1755, Papers. Hamer, 1:245.

17 HL to John White, May 22, 1755, Papers. Hamer, 1:251.

18 Record of Marriage, June 25, 1750, Papers. Hamer, 1:241.
} 
the status of their counterparts in Britain, or so they believed. ${ }^{19}$ A new world was on the rise in the colonies, especially within South Carolina. Henry Laurens was a part of a rising generation of successful, wealthy merchants whose involvement in the public life of the colony sustained that new world.

Having made a comfortable living for himself, Henry Laurens now turned to public service. He was elected to the Commons House of Assembly of South Carolina in September of 1757 . The legislative body of South Carolina enjoyed a rich history of achieving its political goals over the royal governor, the crown's representative. The legislators acted independently of the will of the crown and dedicated their energies to sustaining the market economy of the colony. ${ }^{20}$ This was in part due to what Jack P. Greene refers to as “a marked correlation between” the rise in the colonial elite, most notably the merchants, and the rise in legislative authority. In The Quest for Power, Greene notes that the colonial legislatures attained the upper hand with the royal governors due to a combination of economic and political factors. In South Carolina, it was the independent will of the legislators, who gradually gained more control over economic factors without strong opposition from the royal administration. ${ }^{21}$

This was the world that Henry Laurens entered when he assumed the duties of his office. South Carolina was separated from Great Britain by an ocean but linked to it by a very British ideology of legislative self determination and trade. Furthermore, having to protect itself from territorial incursion from Indians gave South Carolina the opportunity

19 Jack P Greene, The Quest for Powers, the Lower Houses of Assembly in the Southern Royal Colonies: 1689-1776. (Chapel Hill: The University of North Carolina Press, 1963), 5.

${ }^{20}$ Ibid, 9.

${ }^{21}$ Ibid, 11-12. 
to develop both financially and politically. ${ }^{22}$ South Carolina needed a strong defense against the Cherokee, whose territories bordered the colony. With the resumption of hostilities between Great Britain and France during the Seven Years' War, this was a priority. The Cherokee were a major power in the area. South Carolina's periodic encroachments into their territories made them more willing to ally themselves with France. $^{23}$

Though peace had been maintained between South Carolina and the Cherokee due to previous negotiations directly with the British government, incursions by the colonists created a rift. ${ }^{24}$ Finally, in 1761, with threat following counter-threat, South Carolina was prepared to invade the Cherokee, augmented by a force of British troops sent by General Jeffrey Amherst. Henry Laurens saw the dangers of an extended conflict with the Cherokee. South Carolina did not posses the manpower to successfully defend itself from invasion and protracted warfare. Such a conflict would have a negative impact on the entire colonial economy. ${ }^{25}$

Even before his election to Commons, Laurens expressed his views on the rising conflict with France. After hearing rumors of the defeat and rout of Major General Edward Braddock’s forces near present day Pittsburgh in 1755, Laurens confessed to Walter Caddell that "such an event [another war with France] would disconcert all our schemes in North America.” In this, he was referring to the continued existence of the

22 Greene, 298-300.

23 Greene, 310-311.

24 Wallace, 98-100. Several Cherokee chiefs had negotiated an agreement with the British government in 1730, which did not specify a border between the two sides. With the natural population growth that accompanies a healthy economy, South Carolina began to expand into Cherokee territory. Naturally, tensions rose and a conflict between the colonial troops and Cherokee warriors undermined the peace efforts.

${ }^{25}$ Wallace, 101. 
colonies and South Carolina's market economy. Laurens, like any other businessman, was concerned not only with his colony but with the effect that a war would have on his business. ${ }^{26}$

To provide a strong defense, Laurens realized a more cohesive militia unit was necessary. Writing to James Cowles in August of 1755, Laurens commented that General Braddock’s regular forces would have attained a larger degree of success had they pursued the war with colonial militia units as the primary body of troops. ${ }^{27}$ In fact, he continued to uphold this belief in subsequent correspondence. Writing to business associates in England, Laurens again warned that allowing the French forces to advance down the Ohio and Mississippi valleys threatened the security of the colonists and the economy of North America. ${ }^{28}$ In truth, colonial militia units were a part of General Braddock's army in 1775. However, conflicts between colonial militias and British regulars prevented a cohesive military unit from being formed. These problems were an extension of the intrinsic political conflicts between the colonial assemblies and the British government over the funding of the war effort. As a legislator, Laurens was aware of the problems but did not perceive them to be an aggravating factor. ${ }^{29}$

In his letter to Devonsheir, Reeve, and Lloyd, Laurens advocated a colonial union. "Were the several provinces to unite in their strength," he argued, ”we should be able to do anything.” There were other leaders throughout North America who felt this way, but Laurens warned that due to the diverse natures of the various colonial governments, no such coalition would be plausible until "an apparent danger of the whole shall drive them

${ }^{26}$ HL to Walter Caddell, August 15, 1755, Papers. Hamer, 1:319.

${ }^{27}$ HL to James Cowles, August 20, 1755, Papers. Hamer, 1:321.

${ }^{28}$ HL to Devonsheir, Reeve, and Lloyd, August 20, 1755, Papers. Hamer, 1:321.

29 Douglas Edward Leach, Roots of Conflict: British Armed Forces and Colonial Americans, 1677-1763. 
to the necessity of it." ${ }^{30}$ In fact, such an idea had been discussed and rejected by the colonies in 1754. Meeting in Albany, New York, the colonies had unanimously rejected a plan of union proposed by Pennsylvania's Benjamin Franklin and Massachusetts Governor William Shirley. ${ }^{31}$ Experiencing a great deal of frustration at the way the British government was pursuing the war, and concerned with the future of his colony's economy, Laurens continued to voice his opinions on how the war should be prosecuted. As fate would have it, his election to the Commons House in 1757 allowed Laurens to publicly express his feelings on the war.

It was during his service in the colonial legislature that Henry Laurens became a fierce advocate for a stronger defense of South Carolina's borders. Distrustful of what the Cherokee might do in the event of French overtures, Laurens felt the necessity of securing the border and preparing for the worst. Seeing that the public treasury was taxed to its limits, Laurens and other successful South Carolina merchants agreed to contribute funds to the war effort, an action that was widely noted and lauded at the time. ${ }^{32}$

Throwing his energies into providing South Carolina with a strong defense, Henry Laurens was appointed a lieutenant colonel in the colonial militia on September 16, 1760. His commission, signed by Lieutenant Governor William Bull, charged him with the task of organizing a unit of one thousand soldiers. This unit was to be raised to defend South Carolina against a potential invasion by the Cherokee nation. ${ }^{33}$ Though he was re-elected to the Commons in 1760 , he was unable to take his seat as he was preoccupied with his

(Chapel Hill: The University of North Carolina Press, 1986.), 164-165.

${ }^{30}$ HL to Devonsheir, Reeve, and Lloyd, August 20, 1755, Papers. Hamer, 1:321-322.

31 Joseph L. Davis, Sectionalism in American Politics: 1774-1787. (Madison: The University of Wisconsin Press, 1977), 12.

32 Public Subscription, November 17, 1759, The Papers of Henry Laurens, Volume Three: January 1, 1759-August 31, 1763. Philip M Hamer, ed. 2 vols. (Columbia: University of South Carolina Press, 1972), 3:16. 
military duties. ${ }^{34}$ South Carolina's Gazette credits Laurens with being the most successful militia recruiter within the colony. ${ }^{35}$ Another report indicates that Laurens made efforts to recruit soldiers from North Carolina as well and that he met with the Catawba ruler, King Haigler. ${ }^{36}$ The purpose of this meeting was to gain assurances from the Catawba ruler that the colonists could count on their support against the French. King Haigler assured Laurens that his people would maintain peaceful relations with the British and that they would not be swayed by French overtures. This was enough to mollify Laurens and the meeting was reported in the Gazette as "a good talk.”37 Eventually, drawing from both North and South Carolina, Henry Laurens created a militia unit of twelve hundred able men to serve as a buffer. ${ }^{38}$

The militia unit, sponsored and recruited by Laurens, engaged in prolonged warfare with the Cherokee during the year 1761. Though Laurens was not an active participant in the actual battles with the Cherokee, he did accompany the militia to reconnoiter through their territory and was vested with the responsibility of safeguarding close to one thousand sick and wounded soldiers. In a letter to Reverend John Ettwein, Laurens describes how the colonial militia marched "for the middle settlements of the Cherokee Nation, holding the olive branch in one hand and the [word missing] of cruel war in the other, leaving the choice to be made by the people who dwelt there."’39

\footnotetext{
${ }^{33}$ Commission as Lieutenant Colonel, September 16, 1760, Papers. Hamer, 3:46.

${ }^{34}$ Appendix listing of Henry Laurens and his actions in the Commons House, Papers. Hamer, 3:561. This session of the House began in October of 1760 and ended in February of 1761. The house journal lists Laurens as being re-elected to his seat, but requesting leave to pursue his militia activities. Among his many duties, Laurens was also vested with the task of finding funds for the newly established militia unit. ${ }^{35}$ Newspaper Accounts, October 26, 1760, Papers. Hamer, 3:52-53. There are several accounts from the Gazette included in this collection of Henry Laurens' papers. For the most part, the newspaper articles indicate his degree of success while recruiting for the South Carolina militia.

${ }^{36}$ Newspaper Accounts, February 7, 1761, Papers. Hamer, 3:59.

${ }^{37}$ Ibid, 3:34.

${ }^{38}$ Wallace, 101.

${ }^{39}$ HL to John Ettwein, July 17, 1761, Papers. Hamer, 3:73-74.
} 
The Cherokee apparently chose war. Perhaps because of the cruelty with which the colonial militia eventually subdued the Cherokee, the colony of South Carolina was secure in her borders for the duration of the Seven Years' War. ${ }^{40}$ When the Cherokee nation was forced to sue for peace, Laurens was one of the members of the Commons House who escorted the delegation to the temporary capital of South Carolina, Shem Town. The Commons was forced to relocate to the northwest due to an outbreak of yellow fever in Charles Town. ${ }^{41}$ With little choice, given the destruction brought to their settlements, the Cherokee agreed to the terms set forth by the colony. Attakullakulla, one of the principal chiefs of the Cherokee Nation, agreed to accept the partition of some of his lands to establish a border with South Carolina. ${ }^{42}$

With the 1763 end of the Seven Years’ War, Laurens was able to devote more time to his profitable business efforts and return to his seat in the Commons. It was during this time, 1763 until 1775, that the Commons enhanced its power and finally asserted its independence from the crown. The Commons had always exerted its will over the royal administration by insisting that it had the right to appoint revenue collectors and control the public funds used to pay crown appointed officials, including the royal governor's salary. ${ }^{43}$ Disputes over the appointment of judges and the right of the legislature to issue money further aggravated the situation. ${ }^{44}$

\footnotetext{
${ }^{40}$ Wallace, 102. In June of 1761, a regiment under the command of Colonel James Grant pushed deep into Cherokee territory and conducted a scorched earth policy against the towns and villages that they encountered. This campaign is said to have lasted thirty days and inflicted great damage to the Cherokee nation.

${ }^{41}$ Preliminary Negotiations with the Cherokee, September 10-22, 1761, Papers. Hamer, 3: 83. Laurens is mentioned as the person responsible for delivering the records of the preliminary negotiations conducted in the field with the Cherokee leader, Attakullakulla, to Lieutenant Governor Bull and the Commons House.

${ }^{42}$ Wallace, 102.

43 Greene, 358.

44 Ibid, 402-403.
} 
Such quarrels were not new to South Carolina politics, and the Commons had usually attained the upper hand--a fact which Laurens noted quite frequently. Even as early as 1747, Henry Laurens was aware of the distrust with which the people of South Carolina viewed the colonial administration. "The people of the Province are generally very fickle,” he wrote to Reverend Richard St. John in November of 1747, “...especially in respect to Governors Spiritual or Temporal, soon pleased and soon disgusted.”45 Though he wrote this letter to his friend in confidence, Laurens was aware that the interest of colonists and crown representatives often diverged. As the people became more and more dissatisfied with British authority, the Commons House in South Carolina gained importance.

As a result of the prolonged war with France, Great Britain found itself in an increasingly difficult financial situation. King George III referred to the Seven Years' War as a "bloody and expensive" conflict. Though the British were victorious and the American colonies secured, the king forced the resignations of the spendthrift ministers who had prosecuted the war and caused a debt of over 130 million pounds. What followed would bring even more tension between the colonies and the British government. ${ }^{46}$

As a result of a prosperous trade with Great Britain, the American colonies had enjoyed a great degree of economic success. This trade was guided by the Navigation Acts, a series of laws governing the shipping industry. Though the Navigation Acts were originally created to bolster the English shipping industry as it faced Dutch competition,

${ }^{45}$ HL to Richard St. John, November 11, 1747, Papers. Hamer, 1:80.

${ }^{46}$ Wallace, 410. 
they provided a secure system of exchange between the territories of Great Britain. ${ }^{47}$ The acts were meant to assure that certain export items from the colonies were shipped on English vessels, by English crews, and only to English ports. ${ }^{48}$ Colonial merchants were required to attain bonds and certificates attesting that the vessels they were using were English and that their destinations were ports in possession of the British empire. In the years before the Seven Years` War, the British government allowed the colonies to engage in an indirect trade with one another. This lead to a period of economic expansion that allowed the colonies to prosper. ${ }^{49}$

By 1763, the period of unchecked economic and political development had become widely noticed within the British empire. Oliver Dickerson describes an America on the rise, benefiting from trade with Great Britain and growing into thirteen independent political entities. ${ }^{50}$ Meanwhile, England was recovering from the financial effects of another war with France. Dickerson describes the series of legislation that followed as a reorganization of colonial America. ${ }^{51}$ Government ministers and British merchants had seen the rapid political development that had accompanied colonial expansion as an affront to the power of the Parliament to regulate trade, and thereby govern the colonies. ${ }^{52}$

In 1764, the British Parliament passed the Sugar Act, which required a duty of three pence to be paid on items imported from French or Dutch merchants. Included in

${ }^{47}$ Oliver M. Dickerson, The Navigation Acts and the American Revolution. (New York: Octagon Books, 1978), 31-32.

${ }^{48}$ Ibid, 64.

49 Ibid, 64.

${ }^{50}$ Ibid, 149.

51 Ibid, 172.

52 Ibid, 273. 
the list of taxable commodities were molasses, coffee, and sugar. ${ }^{53}$ Violators of this act would be subject to prosecution in Vice-Admiralty courts. ${ }^{54}$ In 1765 , the Parliament adopted the Stamp Act, which required a tax to be paid on all legal documents, playing cards, newspapers, and dice. ${ }^{55}$ Vice-Admiralty courts began to enforce the Navigation Acts on colonial merchants who, in the past, had sidestepped English regulations. It was customary for merchants sending goods from one colony to another to attain a bond to assure that their goods would be shipped according to the Navigation Acts. Henry Laurens always attained the required bonds. ${ }^{56}$

The Stamp Act caused more of an uproar throughout the American colonies than had the previous Sugar Act. In South Carolina, Henry Laurens was confronted with a crisis of conscience regarding the Stamp Act. While he recognized that the legislation threatened the economy of South Carolina, he did not advocate the public upheaval that it caused. He was right to be concerned, as a series of riots and public demonstrations against the bill spread throughout Charles Town in October of 1765. Tax collectors were hanged in effigy, bitter diatribes were directed at the royal governor, and the city entered a period of paranoia over the implementation of this most unpopular legislation. ${ }^{57}$

Though Henry Laurens was not a party to the collection of taxes through the Stamp Act, he was nonetheless a victim of the misdirected rage of his fellow colonists. On October 23, 1765, Laurens was confronted by an unruly mob of colonists who

53 Edmund S. Morgan, The Birth of the Republic: 1763-1789. (Chicago: The University of Chicago Press, 1977), 16.

54 Ibid, 37.

55 James L. Stokesbury, A Short History of the American Revolution. (New York: William Morrow, 1991), 32.

${ }^{56}$ Morgan, 55.

57 HL to Joseph Brown, October 22, 1765, The Papers of Henry Laurens, Volume Five: September 1, 1765-July 31, 1768. George C Rogers, ed. 5 vols. (Columbia: University of South Carolina Press, 1976), 26-28. 
believed that he was holding the stamp seals sent from Great Britain. Startled awake in the early hours of the morning, Laurens confronted the assembled colonists. To make matters worse, Eleanor Laurens was eight months pregnant and quite ill. ${ }^{58}$ Laurens later commented that he knew several of the individuals who were demanding entrance to his home, despite their disguises. ${ }^{59}$ The mob insisted that Laurens was in possession of the offending stamp paper and resolved to search his house--an action he would not consent to, vowing to seek satisfaction with any who dared cross his threshold. While the accusations of those angry colonists were untrue, Laurens was still forced to mollify the crowd. ${ }^{60}$

Having justified his position by pointing to his own public statements against the Stamp Act, Laurens insisted that the crowd disperse. ${ }^{61}$ This incident represents the paranoia that spread throughout the citizenry of South Carolina as legislation from Britain began to have a more visible impact on colonial society. While Henry Laurens also viewed this action as an encroachment of the long enjoyed liberties of the colonists, he did not condone violent street action. What occurred at the Laurens' residence was hardly an isolated incident. Throughout the American colonies, there were similar riots and assaults on tax collectors. The tide of discontent washed over the citizens of the thirteen colonies. ${ }^{62}$ In October of 1765, a conference of colonial representatives was called by the Massachusetts legislature for the express purpose of discussing the

\footnotetext{
58 HL to Joseph Brown, October 26, 1765, Papers. Rogers, 5:37.

59 Ibid, 5:38. In this letter, Laurens says that those people that he recognized were dressed a sailors and had their faces obscured by soot.

${ }^{60}$ Ibid, 5:39. The crowd believed that due to Laurens' friendly relationship with Governor James Grant he was a participant in the scheme.

61 Ibid, 5:39.

62 A.J. Langguth, Patriots: The Men Who Started the American Revolution. (New York: Simon and Schuster, 1989) 54-55.
} 
situation. Nine of the thirteen colonies sent representatives to the Stamp Act Congress, which met in New York City. ${ }^{63}$ While Laurens was not in favor of the Stamp Act, he could not support the creation of such an extra-legal body. He furthermore refused to sign the resolves of South Carolina's Committee of Correspondence, which updated her agents in London as to the situation in the colonies. ${ }^{64}$

In New York City, the Stamp Act Congress drafted a series of resolutions outlining their position against the legislation. ${ }^{65}$ After the repeal of the Stamp Act in 1766, a new series of problems came to light along with a new colonial resolve. Laurens foresaw these problems when he received word of Parliament's decision that it "had a right to Tax the Colonies.”66

The Declaratory Acts of 1766, passed the same day that Parliament repealed the Stamp Act, asserted the authority of Parliament over the colonial governments. ${ }^{67}$ The Townshend Acts, adopted in 1767, imposed a duty on various imports for the purpose of paying the salaries of royal officials in the colonies. Riots and demonstrations filled the streets of America's major cities, as civil unrest and political dissent became a concerted public outcry. Writing to Lachlan McIntosh, Laurens commented that his colony would "not subscribe to the right of a British Parliament to lay internal taxes upon America." He concluded that South Carolina, like all the other colonies, would "sullenly and stubbornly resist against all ministerial mandates and admonitions tendering to enslave them.”보 In 1768, the South Carolina Commons and Governor Charles Greville Montagu

\footnotetext{
${ }^{63}$ Morgan, 22.

${ }^{64}$ Committee of Correspondence to Charles Garth, December 16, 1765, Papers. Rogers,5: 44.

${ }^{65}$ Stokesbury, 32.

${ }^{66}$ HL to John Lewis Gervais, May 12, 1766, Papers. Rogers, 5:129.

${ }^{67}$ Greene, 374.

${ }^{68}$ HL to Lachlan McIntosh, October 15, 1768, The Papers of Henry Laurens, Volume Six: August 1, 1768July 31, 1769. George C Rogers, ed. 5 vols. (Columbia: University of South Carolina Press, 1978), 6:127.
} 
clashed over the legality of Parliament's decision to legislate for the colonies. When the governor dissolved the house in November, the legislative discontent continued when it reconvened in August. At its inaugural meeting, the Commons adopted a plan of nonimportation of British goods in protest of the Townshend Acts--similar agreements were made by other colonies throughout the year. ${ }^{69}$ During the next two years, Laurens demonstrated a dedication to the non-importation agreement, claiming it was a lawful assertion of colonial rights. ${ }^{70}$

At this time, Laurens himself became a victim of the Navigation Acts. Several of Laurens' shipments were stopped at their ports and his vessel, the Wambaw, was seized at Charles Town harbor. Although, Laurens had purchased the bond required by law and forwarded it to the appropriate customs official, his vessel was still held at port. Laurens was forced to pay court costs for his efforts to set the situation right, a common occurrence in both the Carolinas. ${ }^{71}$

Other prominent merchants experienced similar treatment, with shipments detained by royal customs officials. Despite a series of protests to the ministry sent to South Carolina’s colonial agent in London, Charles Garth, the British government did nothing to rectify the situation. Tensions rose and Laurens was challenged to a duel by customs collector Daniel Moore, who had held his ships at port. Moore avoided the appointment and fled to Georgia; he was relieved of his position in $1769 .^{72}$ There were other conflicts between royal officials and merchants in South Carolina from 1763 to

\footnotetext{
69 Greene, 376-377.

70 Meeting Under the Liberty Tree, Gazette article, May 10, 1770, The Papers of Henry Laurens, Volume Seven: August 1, 1769-October 9, 1771. George C Rogers, ed. (Columbia: University of South Carolina Press, 1979), 7:290.

71 HL to James Habersham, September 5, 1767, Papers, Volume Five. Rogers, 293-295.

72 The Departure of Daniel Moore, Papers, Volume Five. Rogers, 287-288.
} 
1776--widening the rift between the royal government and the colonists. ${ }^{73}$

Manifestos and bitter diatribes were exchanged between the colonial assemblies and the crown appointed administrators throughout the remainder of the 1760s. Attitudes were changing as a result of British policy. Merchants and political leaders of the colony became dissatisfied with their status within the empire. This issue pushed South Carolina and other colonies towards independence. A coastal market economy in which the independent merchants reigned now found itself subject to the dictates of royal appointees. This was not acceptable for South Carolina and most certainly not for men like Henry Laurens. ${ }^{74}$

Another shake up in the British government found one Prime Minster being ushered out the door while another was stepping up to take charge. In March of 1770, Lord North repealed all of the duties imposed by the Townshend Acts, except for the one on the importation of tea. ${ }^{75}$ Though Henry Laurens had always advised caution when it came to confronting the British government, he was also an avid proponent of local government and he considered the Townshend duties an affront to South Carolina's legislative independence. ${ }^{76}$ While the American colonies were British territories, and the colonists British subjects, they were also a part of a new cultural identity that was taking shape. ${ }^{77}$ In Becoming America, Jon Butler discusses the rise of this new identity as being part of a gradual process. As a result of the combination of various nationalities, and the isolation from Great Britain itself, society in the thirteen colonies had been reshaped into

\footnotetext{
73 HL to James Habersham, September 5, 1767, Papers, Volume Five. Rogers, 296. Laurens mentions that he did in fact strike Mr. Moore in their verbal altercation, but only because he was provoked to do so.

74 Newspaper Account, September 7, 1767, Papers. Rogers, 5: 300-301.

75 Morgan, 49.

${ }^{76}$ HL to Charles Mill, August 7, 1769, Papers. Rogers,7: 116.

77 Meeting Under the Liberty Tree, May 14, 1770. Papers. Rogers, 7: 292.
} 
something different from that of the British. The colonies developed their own economies, their own political traditions, and their own cultural identity. ${ }^{78}$

Cautious in his approach to anything resembling separation, Laurens warned of possible dangers. He disapproved of rioting and acts of violence, favoring discourse and diplomacy as the only ways to achieve a desired end. He supported the colonies in the adoption of the non-importation act in 1768, a legal protest to the taxation of items such as tea, glass, and paper. ${ }^{79}$ However, the repeal of all the Townshend duties, save the one on tea, did not improve the situation in the colonies. ${ }^{80}$ Laurens approved of nonimportation, despite personal financial loss, until the colony of South Carolina abandoned the plan in December of 1770 . However, it is clear from his writings that the act had an impact on his standard of living. "I am not worth so many pounds, shillings, and pence as you knew me worth in April, 1764," he wrote to George Appleby in September of 1769. During the non-importation agreement, Laurens survived by selling the crops grown at his home, Mepkin Plantation; but his import business was seriously effected. ${ }^{81}$ Nonetheless, Henry Laurens endured. ${ }^{82}$

As the situation in the colonies grew worse, Laurens elected to dedicate his energies to achieving from Great Britain a more conciliatory policy towards North America. In letters to business associates in London, as well as to South Carolina's colonial agent, Laurens warned of the ever increasing dangers of suppressing American autonomy. While he never espoused independence, he did fully embrace the concept of

\footnotetext{
${ }^{78}$ Jon Butler, Becoming America: The Revolution Before 1776. (Cambridge: Harvard University Press, 2000), 2-3.

79 HL to John Knight, October 23, 1769, Papers. Rogers, 7: 172.

80 HL to Bright and Milward, September 10, 1770, Papers. Rogers, 7: 355-356.

81 HL to George Appleby, September 26, 1769, Papers. Rogers, 7: 151.

82 HL to John Hopton, January 29, 1771, Papers. Rogers, 7: 429-430.
} 
America as a self-governing entity within Great Britain. This was not a new concept, nor was it a construct wholly of South Carolina, but was a rapidly growing belief among many colonists. ${ }^{83}$

The tense situation within the thirteen colonies and the death of his wife, Eleanor, in 1770 gave impetus to Laurens’ decision to relocate to England. In 1771, Henry Laurens took up residence in London to see to the education of two of his sons, John and James. His time in London gave him the opportunity to evolve personally as well as politically and alter some of his views on the state of affairs between the colonies and Great Britain. ${ }^{84}$

Laurens found that the academic institutions in London did not provide the education that he wished his sons to have. He therefore sent John and James to a school in Geneva, Switzerland, where science and mathematics were stressed and moral virtues were rigidly enforced. This, he felt, would provide his sons with a well rounded education and prepare them for life in a civilized society. ${ }^{85}$ Laurens lauded the studious nature of the Swiss instructors, whom he saw as paragons of virtue. It was only after the boys had completed their schooling in Switzerland that Laurens resolved to further their education in England. By this time, his ten year old son, also named Henry, had joined them. ${ }^{86}$

Though he was re-elected to the Commons in 1772, he was unable to return from England and would most likely have declined the offer had the royal governor not once

\footnotetext{
83 Wallace, 166.

84 HL to William Cowles, October 29, 1771, The Papers of Henry Laurens, Volume Eight: Oct. 19, 1771April 19, 1773. George C. Rogers, ed. 5 vols. (Columbia: University of South Carolina Press, 1980), 8: 19.

${ }^{85}$ HL to Alexander Garden, May 24, 1772, Papers. Rogers, 8: 325.

86 HL to James Laurens, June 22, 1772, Papers. Rogers, 8: 375-376.
} 
more dissolved the house. ${ }^{87}$ Laurens continued to advocate colonial rights to members of Parliament and observed the political situation in Great Britain. ${ }^{88}$ Returning to South Carolina in November of 1774, Laurens was subsequently elected to the First Provincial Congress, which was established to enforce the non-importation of tea from Great Britain. $^{89}$ By the summer of 1774 , a general call for representatives expanded this body into an assembly of over one-hundred colonists. After redistricting and agreeing on a parliamentary format, the organization became a legislature in January of 1775 . Though they were not quite ready to supplant the royal administration, the colonial representatives present were preparing to assert their long upheld belief of selfdetermination.

In a letter to his son, John, Laurens asks the student’s counsel regarding the colonial determination "to make a firm and steady opposition to the measures adopted by administration for enslaving us and our property."90 Laurens referred to the creation of the First Continental Congress and its assertion that the colonists alone could legislate for the individual colonies. This was not only a bold move by the colonists, but was treason in the eyes of any loyal Englishman. The congress, however, invoked English law in this assertion and claimed that as part of that canon, the "people have a right to participate in their legislative council." ${ }^{91}$ With the petition by the congress to the people of Great Britain, Laurens soon saw that the situation would not quickly mend itself.

With the decision of the First Continental Congress to adopt measures that barred

${ }^{87}$ HL to James Laurens, May 13, 1772, Papers. Rogers, 8: 305.

88 HL to John Laurens, August 21, 1772, Papers. Rogers, 8: 438-439.

89 HL to John Laurens, June 8, 1773, The Papers of Henry Laurens, Volume Ten: December 12, 1774-

January 4, 1776. David R Chesnutt, ed. 7 vols. (Columbia: University of South Carolina Press, 1985), 10: 3.

90 HL to John Laurens, December 12, 1774, Papers. Chesnutt, 10:3-4

91 Morgan, 65. 
the importation of British goods, and the widening gap between the mother country and the colonies, Laurens feared not only for his homeland but for businesses. ${ }^{92}$ The next stage of Laurens' political evolution began in 1775, as he moved toward revolution. With all the colonies suffering "violations of faith and credit" and being "unjustly treated by the mother country,” Laurens was uncertain over which path to take. He confesses his feelings to a friend living in London, hoping "that the wisdom of your new Parliament will deliver us from the deplorable state to which we are reduced by the folly of their predecessors." ${ }^{93}$

Though the Provincial Congress of South Carolina styled itself the legislature of the colony, there was no legal basis for such a claim. This body nonetheless operated as a government body, even providing for representatives to be dispatched to the Second Continental Congress. Though Laurens was wary of the dangers of any military conflict with Great Britain, he nonetheless stood up for the rights he believed that colonies possessed--the most sacred of these, the right to self-determination of economic and political affairs. ${ }^{94}$ As each day brought more news of the rising tide of dissent within the colonies, South Carolina moved nearer to chaos. The Provincial Congress gradually took over the powers presumably exercised by the Commons House. This was the revolution as it started in South Carolina, with a new legislature at the head of an emerging state. ${ }^{95}$ In a letter to his son, John, Laurens bewailed the course his colony was taking and confessed that he wept for the circumstances that provoked the leaders of his colony to

\footnotetext{
92 HL to Ross and Mill, January 3, 1775, Papers. Chesnutt, 10: 10.

93 HL to William Manning, January 4, 1775, Papers. Chesnutt, 10: 20.

94 HL to John Laurens, January 18, 1775, Papers, Volume Ten. Chesnutt, 27-31. In this letter, Laurens explains the actions of the Provincial Congress in supporting the resolutions of the First Continental Congress, and voices his fears over the coming storm.

95 HL to John Laurens, January 22, 1775, Papers, Volume Ten. Chesnutt, 39-40.
} 
choose such a course. "I feel for the distress of my country," he wrote, "I weep for the horrid effects of civil discord which must soon be produced if we proceed in our contest with Great Britain.”96 His letters throughout the year 1775 reflect his concern over the rise of dissent among the colonists, the landing of British troops on North American soil, and even the potential for armed conflict. ${ }^{97}$

As the fledgling revolutionary government of South Carolina grew, Henry Laurens continued to serve as a more moderate voice in the affairs of state, yet always insisting that the colonies had the right to legislate for themselves. When the Provincial Congress ordained a Council of Safety in June of 1775, to provide leadership for the colony during its recess, Henry Laurens was elected president. At the inaugural meeting of this body, regulations for the governing of the colonial militia were established and a general treasury was created to provide funds to operate the government. ${ }^{98}$ Like his contemporaries in the business elite, Henry Laurens wished to avoid war and seek out political reconciliation. Indeed, these were the thoughts that he expressed to his business associates in London as well as to his most trusted confidante, his son, John.

This was not a new concept, nor was it considered altogether foolish given the circumstances surrounding the rebellion in North America. Aside from the obvious fears that such a war aroused, namely thirteen colonies battling what was considered to be the greatest empire in the world, there were also economic considerations. The colonies had benefited from their relationship with Great Britain and had, for the most part, enjoyed a lengthy period of economic prosperity. Consequently, a war with the mother country

\footnotetext{
96 Ibid, Chesnutt, 41.

97 HL to John Delagaye, January 25, 1775, Papers, Volume Ten. Chesnutt, 47-50.

98 HL to John Laurens, June 18, 1775, Papers. Chesnutt, 10: 182-183.
} 
would shut down the harbor towns of South Carolina, which were the life blood of the colony's economy.$^{99}$ Laurens and other members of South Carolina's merchant class felt this sting as 1775 drew to its close.

As president of the Council of Safety, Laurens oversaw the raising of troops for the protection of South Carolina and the dispersal of funds to provide for the arming and clothing of those troops. ${ }^{100}$ With the beginning of the Second Provincial Congress on November 1 of 1775, Laurens remained active in the legislative affairs of his colony, serving on several important finance committees. When the first session of the Second Provincial Congress adjourned on November 29, 1775, the government of the colony was once more left to the Council of Safety. Council president Henry Laurens continued his defensive preparations. ${ }^{101}$ During this time, British vessels were expelled from the harbors of South Carolina and a series of fortifications were built for the purposes of defense. Revolution had begun and the rift between the colony and the mother country was widening. ${ }^{102}$

Throughout the final months of 1775, Laurens and the Council of Safety were engaged in preparing for war with Great Britain. The colonists erected forts, raised militia units, and dispersed funds to support the defense of the state. The situation was grave as Laurens warned of the eminent arrival of British warships. ${ }^{103}$ To make his burden worse, Laurens received word that his son, James, had died suddenly in London

\footnotetext{
99 Alan Nevins, The American States During and After the Revolution: 1776-1789. (New York, The MacMillan Company, 1927), 110.

100 Letters of the Council of Safety, Papers. Chesnutt, 10: 502-507. These letters outline the defensive preparation undertaken during Henry Laurens’ presidency of the Council of Safety. These letters were dispatched between October 24 and November 29 of 1775.

101 Council of Safety to Andrew Williamson, December 2, 1775, Papers. Chesnutt, 10 :524.

102 Wallace, 220.

103 Council of Safety to Stephen Bull, December 6, 1776, Papers. Chesnutt, 10: 538-539.
} 
in September of $1775 .{ }^{104}$ Grieved, he was forced to bear this sorrow as well as the mantle of leadership. As loyalist regiments prepared to battle the colonists, South Carolina exchanged its provincial status for a new designation--independent state. The machinery of war had been prepared and though Laurens feared the result, he endeavored to defend his charge. ${ }^{105}$

When the Second Provincial Congress reconvened in February of 1776, it quickly took up the duties of government for the colony. The body was aided in this endeavor by the absence of Governor Lord William Campbell, who had fled to the newly arrived warship Cherokee in Charles Town harbor over fears of a popular uprising. The Council of Safety had made adequate defensive preparations during the recess, while at the same time entreating Lord William to return and make peace with the colonists. In a letter addressed to the governor, Laurens requested Campbell return to the capital, provided he "take no active part against the good people of this colony." 106 Having no interference from the royal administration, the Provincial Congress moved to solidify the break with the mother country. After intense debate over the powers and functions of the entities of statehood, the congress "metamorphosed in the twinkling of an eye into a General Assembly, from whence a President and Commander-in-Chief, Vice-president and Privy Council, a Legislative Council and divers officers of state have been chosen by ballot.”107 Despite his best efforts to prevent this, Laurens was elected to the post of Vice-

104 Letter from John Laurens, October 4, 1775, Papers. Chesnutt, 10: 453. John Laurens wrote his father to inform him of this tragic news, and though he received it with all the heartbreak a father hearing of such an event could fell, he was too engrossed with his duties to speak of it until much later.

105 Wallace, 221.

106 HL to Lord William Campbell, September 29, 1775, Papers. Chestnutt, 10: 435.

107 HL to John Laurens, March 28, 1776, The Papers of Henry Laurens, Volume Eleven: January 5, 1776November 1, 1777, David R Chesnutt, ed. 7 vols. (Columbia: The University of South Carolina Press, 1988), 11: 194. 
president of the newly styled state of South Carolina. "I went so far yesterday," he confessed to his son, John, "as to retire from the House under this declaration that I would not serve, whether another has been chosen I know not." ${ }^{\text {"108 }}$ After the adoption of the South Carolina constitution, Laurens continued to maintain hope that the grievances between Great Britain and the mother country would be resolved. ${ }^{109}$ Laurens did not advocate revolution; seeing the dangers of such a contest, he still entertained hopes for a reconciliation with the mother country. When he received word of the adoption of the Declaration of Independence by the Continental Congress, he lamented that the action was made necessary. ${ }^{110}$

Henry Laurens was not born a revolutionary. He was a product of the era in which he lived. As a merchant, he felt his livelihood endangered by the incursions of the British Parliament. As a political leader in South Carolina, he viewed the assertion of Parliamentary power over the colonies as an infringement of American rights. Laurens did not start out as an advocate of separation, in fact he preferred reconciliation over absolute independence. In his thinking, the colonies already possessed the right to legislate for themselves. As an integral part of the British empire, the colonies of North America were a new frontier. In the mind of men like Henry Laurens, the British Parliament's decision to impose taxes on the colonies represented a gross abuse of legislative authority. As the door was closed on the issue of reconciliation, Laurens moved into the next stage of his public evolution.

On January 10, 1777, Henry Laurens collided with his destiny and began the most

\footnotetext{
108 Ibid, 11: 194.

109 Ibid, 11: 195-196.

110 HL to Babut and Company, August 5, 1776, Papers. Chesnutt, 11: 220.
} 
challenging endeavor of his public life. "I am ordered to the Congress of the United States," he wrote to John Laurens in February of 1777, "I said it would be impossible for me with any propriety to leave this place before the month of May, the vote was confirmed, I call it therefore as I feel it, a Command--I go.” Elected as one of South Carolina's delegates to the Second Continental Congress, Laurens grudgingly accepted this "command" and set his affairs in order for the journey to Philadelphia. ${ }^{111}$ His previous experience and service to the public had conspired to prepare him for the task that awaited him. However, in the months to come he would face his most difficult challenge of all--sustaining a new nation.

${ }^{111}$ HL to John Laurens, February 3, 1777, Papers. Chesnutt, 11: 293. 


\section{Chapter Two: A Harsh Winter}

Henry Laurens viewed his election to the Continental Congress as an arduous “command” that must be obeyed despite the personal sacrifice involved. Eleanor Ball Laurens had died in 1770, leaving Henry Laurens a widower. With the death of James and having to see to the education of John Laurens, Henry Laurens was pulled in several directions. His personal concerns were heightened by business problems caused by the conflict with Great Britain. Military concerns added to Laurens’ cares as he strove to secure South Carolina's borders. It is understandable that he viewed his election to the Congress with dread. Moreover, a series of troubling events were beginning to threaten the stability of the American Confederation, not to mention the war effort. Lack of supplies and financial deficiencies, compounded with a serious dispute over the future of General Washington's command, endangered the success of the American cause. In Congress, Laurens overcame his personal concerns to provide the firm leadership that America needed to overcome this and other crises.

Arriving in Philadelphia on July 21, 1777, Laurens quickly learned of the approaching danger posed by British forces. "We are assured from good authority that this city is the object of the campaign,” he wrote to John Lewis Gervais in reference to the reports of General Sir William Howe's movements toward the capital. ${ }^{112}$ In this same letter, Laurens discusses the need for alliances with European nations. Thinking of the future of the country, Laurens realized that the states would need financial as well as military assistance from nations such as France, Spain, and the German states. ${ }^{113}$ Indeed, his actions throughout the coming year were motivated by his concern for the financial

112 HL to John Lewis Gervais, August 5, 1777, Papers. Chesnutt, 11: 420-421.
113 Ibid, 11: 425. 
strain placed on the general government by the war with Great Britain.

The necessity of negotiating an alliance with France gave Laurens the most concern. The two major issues faced by Laurens in the early months of his presidency threatened that alliance. As a result of the machinations of Silas Deane, who had been appointed by the congress to assist Benjamin Franklin in France, Philadelphia was overrun by French nobles seeking commissions in the Continental Army. Deane had promised several influential nobles commissions as a means of gaining support from the French government. ${ }^{114}$ While Laurens agreed that worthy French officers might assist the Continental Army, he did not approve of Deane's actions because it placed Congress in an awkward position. As Laurens explained in his letter to John Lewis Gervais, "if we employ [the Frenchmen] with all his unwarranted contracts, many of our best generals will be grossly affronted.” However, Laurens realized that if congress refused to accommodate these individuals, the potential for an alliance with France could be put in grave jeopardy. ${ }^{115}$

When it became apparent that the Continental Congress could not accommodate every request, angry letters from distraught commission seekers were sent to Philadelphia. This discontent led Laurens to consider the potential for “disparaging reports of Congress at the Court of France,” which would negatively affect the French view of the United States. Laurens confessed that the proper course of action would be to remove Silas Deane from his position as a Commissioner to France and replace him with

\footnotetext{
114 Worthington C. Ford, ed. Journals of the Continental Congress, Volume Nine-1777:October 3December 31. 37 vols. (Washington: Government Printing Office, 1907), 9: 875-876.

${ }^{115}$ HL to John Lewis Gervais, August 5, 1777, Papers. 11: 422.
} 
another representative. ${ }^{116}$

Laurens did understand the importance of advancing some worthy foreign individuals such as the Marquis de Lafayette, whom Laurens felt was a dedicated patriot. In the next few months his interaction with the Marquis developed into a personal friendship. ${ }^{117}$

Three weeks into his congressional service, Laurens noticed a serious deficiency in the way in which the Continental Congress managed the affairs of the nation. With conflicting reports from General Washington of the disposition of British forces further complicating the situation, Laurens began to express his concerns over the future of the American Revolution. New York was occupied by the British under General Sir William Howe, its harbor blockaded by warships under the command of Admiral Richard Howe. The Commander-in-Chief of the Continental Army, General George Washington, was trapped in New Jersey and in desperate need of money. ${ }^{118}$ Knowing that General Howe had advanced towards Philadelphia, the Continental Congress began to make a contingency plan should the seat of government be occupied. ${ }^{119}$ "Congress in the present situation of affairs think it necessary to prepare for adjourning to Lancaster,” Laurens wrote to George Galphin in September of 1777, “...perhaps before sun rise tomorrow, I shall be on my journey." ${ }^{120}$

As a precautionary measure, several members of the Continental Congress left the city. “We keep enough to make a Congress, and that’s all,” Laurens wrote to John Lewis

${ }^{116}$ HL to John Rutledge, August 12, 1777, Papers. Chesnutt, 11: 448. Congress would officially recall Deane on November 21, 1777. He would, however, remain in Paris.

${ }^{117}$ HL to John Lewis Gervais, August 5, 1777, Papers. Chesnutt, 11: 423.

118 Morgan, The Birth of the Republic, 79-80.

119 Worthington Chauncey Ford, ed. Journals of the Continental Congress, Volume Eight-1777: May 22October 2. 37 vols. (Washington: Government Printing Office, 1907), 8: 742.

${ }^{120}$ HL to George Galphin, September 16, 1777, Papers. Chesnutt, 11: 523. 
Gervais, "I shall remain as long as any--I sent my baggage forward some days ago and can easily transport myself." ${ }^{121}$ While the simple majority that remained in the capital began to debate "the weighty business of confederation," Laurens kept one eye on his flight and the other on the duties at hand. ${ }^{122}$ When it became apparent that General Howe and his forces were close to Philadelphia, Laurens was one of the last members of the Continental Congress to vacate the city. ${ }^{123}$

After his arrival in Lancaster, Pennsylvania, the seat of government for the exiled Continental Congress, Laurens appraised the leadership of his state of the situation. In a letter to John Lewis Gervais, Laurens describes his calm withdrawal from Philadelphia, along with many of the town's patriot residents. "Thousands of all sorts in all appearances past by in such haste," he wrote, "that very few could be prevailed on to answer to the simple question, what news?" "I, however, would not fly,” he concluded, "I stayed breakfast and did not proceed till 8 o'clock."

While exiting the city, Laurens happened by the wounded Marquis de Lafayette, who had been struck by a British musket ball during the battle of Bristol. Laurens' respect for the young Marquis' leadership abilities and courage increased after this meeting. He safely deposited the young French soldier in the city of Bethlehem before joining the rest of the Congress at Lancaster on September 27, $1777 .{ }^{124}$

Laurens began communicating with the Marquis after learning of his swift recovery from his wounds, informing the Frenchman that his belongings and correspondence were being sent to him in the field. Praising his actions in the recent

${ }^{121}$ HL to John Lewis Gervais, September 18, 1777, Papers. Chesnutt, 11: 528.

122 Ibid, 11: 528. The adoption of the Articles of Confederation had been discussed before the evacuation of Congress, with no solution presenting itself.

${ }^{123}$ HL to Robert Howe. October 20, 1777, Papers. Chesnutt, 11: 570-573. 
battle, and lauding him for his swift recovery, Laurens made efforts to develop a cordial relationship with Lafayette. This action was motivated by his personal interest in the young man, but it also worked to cement relationships between France and the United States. Lafayette's support and considerable wealth were important factors in maintaining a positive relationship. ${ }^{125}$

After realizing that Lancaster would not support the departments of the government, the Congress elected to set up a capital in the city of York, Pennsylvania. On September 27, 1777, the Continental Congress resolved "that the Treasury Board direct the treasurer, with all his papers, forms, etcetera to repair to the town of York."126 Moving the various records and personnel proved difficult but altogether necessary. It was at York that the Continental Congress lost one of its oldest proponents, and would gain one of its most dedicated leaders. John Hancock resigned as President of the Continental Congress on October 31, 1777, leaving vacant the post he had occupied for over two years. The congressional record for that day gives no intimation as to why the president would relinquish his duties. The record only states that Hancock stated that he had served in the capacity long enough. ${ }^{127}$ On November 1, 1777, Delegate Henry Laurens was elected to fill this void. As an outsider in national affairs, Laurens was not an outspoken member of the Continental Congress. He therefore did not have the time to take a stance on issues that divided the national legislature. Subsequently, he did not make enemies within the government. His efforts to maintain neutrality on issues of

\footnotetext{
${ }^{124}$ HL to John Lewis Gervais, October 8, 1777, Papers. Chesnutt, 11: 547.

${ }^{125}$ HL to the Marquis de Lafayette, October 23, 1777, Papers. Chesnutt, 11: 581.

${ }^{126}$ Ford, JCC ,8: 755.

127 Ford, JCC, 9: 852.
} 
concern made him the perfect candidate to lead the Congress. ${ }^{128}$

The duties of the office of President of the Continental Congress were enough to weaken the strongest revolutionary. It was a thoroughly exhausting, constantly thankless position that brought with it the burden of a new nation's survival. It is understandable that Henry Laurens voted against his own nomination and tried to refuse the office when it was conferred upon him. ${ }^{129}$ The path that Laurens had been compelled to take was a rocky one and before his term was up he not only redefined his position, he corrected the course of government for the United States of America.

Perhaps it was the realization of the enormity of the task before him that compelled Henry Laurens to vote against his own nomination to succeed John Hancock. ${ }^{130}$ The duties of the President of the Continental Congress were more than one person could sufficiently deal with. Though his scope of authority was undefined, Henry Laurens was to serve as the conduit through which the decisions of the Continental Congress reached the struggling young nation.

In his first letter to the states, President Laurens apprised the governments of the United States that despite the removal of the Congress to York, the war was not lost. In fact, a significant victory had been scored during the hasty removal of the government from Philadelphia. In October of 1777, British forces under General John Burgoyne had been defeated by American forces under Major General Horatio Gates in the battle of Saratoga, New York. When news of this victory reached the Congress, a day of

128 Ibid, 9: 854.

${ }^{129}$ HL to George Washington, November 13, 1777, The Papers of Henry Laurens, Volume Twelve: November I, 1777-March 15, 1778. David R Chesnutt, ed. 7 vols. (Columbia: University of South Carolina Press, 1990), 12: 49-50. President Laurens wrote this letter in response to a congratulatory note from the general the previous week. In this document, the true weight of the position starts to become apparent.

${ }^{130}$ Notation, Papers. Chesnutt, 11: 593. 
thanksgiving was proclaimed. "The arms of the United States of America having been blessed in the present campaign with remarkable success,” he wrote, “Congress have resolved to recommend that one day, Thursday the $18^{\text {th }}$ December next be set apart and observed by all the inhabitants throughout these States for a General Thanksgiving."”131 The first message contained hope for an American victory and solemn prayers for deliverance from the specter of war.

Aside from communicating with the individual state governments, Laurens was also vested with the responsibility of updating the Commander-in-Chief of the Continental Army of the progress of congressional policies. Almost immediately after assuming the chair of the congress, Laurens received letters from General Washington complaining of a lack of funds and a severe need of clothing for the Continental Army ${ }^{132}$ The general also informed the new president that it would be beneficial to the American cause to have the Marquis de Lafayette in service as a Major General of Continental forces with his own command. ${ }^{133}$ At the same time, Laurens was apprised of the conditions of General Burgoyne’s surrender to Major General Horatio Gates. Lieutenant Colonel John Laurens sent a hand written copy of the negotiations and the final settlement to his father on November 5, 1777. General Burgoyne agreed to Gates’ terms and his men were allowed to leave the battle site with their arms under the proviso that they not serve in North America again. ${ }^{134}$

Laurens wasted no time in responding and immediately reported this important

${ }^{131}$ Circular to the Governors, November 1, 1777, Papers. Chesnutt, 11: 592.

132 George Washington to HL, November 1, 1777, Papers. Chesnutt, 12: 5-6.

133 Ibid, 12: 8-9.

134 John Laurens to HL, November 5, 1777, Papers. Chesnutt, 12: 27-28. 
military success to the Continental Congress. ${ }^{135}$ There was little time to enjoy this news, however. On November 11, 1777, General Washington reiterated his requests for more money and more clothing for the Continental Army. ${ }^{136}$ In response to Washington's letter, Laurens informed the general that the Treasury was severely depleted and therefore it would take time to send the necessary funds. Aside from the cost of moving the Congress several times and the money it had already expended supplying the army, there were other reasons for the near bankrupt status of the Continental Treasury.

In a letter to John Lewis Gervais, Laurens commented that the congress had, as a matter of protocol, given "sums to these disappointed speculatists who had been induced to cross the Atlantic from hearing that there was 'a fine war' in this side.” In this, Laurens referred to the foreign officers and nobles, most of whom were French, who had been enticed by Silas Deane to seek commissions in the Continental Army. ${ }^{137}$ Congress had resolved to pay these French officers enough money to cover their travel expenses back to France or to territories within the French sphere of influence. The resolution of the congress agreed to compensate these individuals "according to their respective stations.”138

Frustrated at not being able to effectively assist General Washington, Laurens began to worry about the state of affairs for the new national government. However, referring Washington's request for additional clothing directly to the Board of War, Laurens sought a speedy solution. When the board determined that the best course of action would be to seek out private merchants to supply the army, Laurens immediately

\footnotetext{
135 HL to William Heath, November 8, 1777, Papers. Chesnutt, $12: 37$.

136 George Washington to HL, November 11, 1777, Papers. Chesnutt, 12: 43-47.

137 HL to John Lewis, Gervais, November 18, 1777, Papers. Chesnutt, 12: 73.

138 Ford, JCC, 9: 876.
} 
sent orders to Boston for that purpose with the approval of Congress. ${ }^{139}$ This is the first instance in which Henry Laurens stepped beyond the limited scope of political authority.

Although he had no executive authority, occupying the presidency allowed Laurens to "move" Congress towards certain actions. ${ }^{140}$ Directing the agenda of the Congress permitted Laurens to submit the most important requests directly to the appropriate boards. Sidestepping official congressional protocol seemed the best course of action, allowing important requests to be evaluated by the appropriate boards.

When other military figures pressed congress for funds, President Laurens went directly to the chairman of the treasury board and enquired as to the status of the continental treasury. He also advised the members of congress to seek other funding sources within their respective states to assist with the pressing financial crisis. ${ }^{141}$ To lessen the financial burden faced by the Congress, it was resolved that all measures be employed to secure such items as blankets and shoes. ${ }^{142}$

To confront the problem of supplying the Continental Army, Laurens and the Congress wrote directly to the individual states to seek out their assistance. Laurens informed the Clothier General of the Continental Army, James Mease, that orders from Congress had been sent to Boston authorizing the purchase of shoes and clothing for 10,000 soldiers. In this letter, Laurens commented that though the orders of the Congress only mentioned Boston as a source of supplies, that Mease should also make such arrangements with Salem and Newberry Port. Laurens further commented that he had sent letters to the Massachusetts Assembly outlining his request, as well as the orders of

\footnotetext{
139 HL to George Washington, November 13, 1777, Papers. Chesnutt, 12: 53.

140 Ibid, 12: 53.

141 HL to Horatio Gates, November 14, 1777, Papers. Chesnutt, 12: 55.

142 Ford, JCC, 9: 906.
} 
the congress. Although the orders from the Continental Congress did not include the towns of Newberry and Salem, Laurens commented, "I am sure it was so intended." Knowing of several prominent merchants within these towns who supported the cause gave the president a marked advantage over some of his congressional colleagues who were not in trade. ${ }^{143}$ Perhaps these additional locations were overlooked by the Board of War and by the Congress. However, it was Laurens who recognized the importance of deviating from the exact wording of the congressional dispatch and took the appropriate steps.

While he was adhering to the dictates of the Congress, Laurens used his own methods. He was not reluctant to express his own sentiments in correspondence as seen in many of his letters to the state governments and to General Washington and the Marquis de Lafayette. When James Mease later pressed Laurens for more money to purchase additional supplies, Laurens sidestepped the congressional protocol that required him to submit this request through the treasury board and went directly to the Congress. The request was immediately taken up at the president's insistence and passed by the congress. ${ }^{144}$

When Congress resolved to seek military supplies through its commissioners in Europe, Laurens contributed his own opinions to the debates, speaking not only as a delegate but as the president of the Congress. The resolution of congress only outlined the purchase of gun powder and lead from European markets. However the president felt that it would be best to seek out "three or more proper persons, skillful in working lead

${ }_{143}$ HL to James Mease, November 17, 1777, Papers. Chesnutt, 12: 71.

${ }^{144}$ Worthington Chauncey Ford, ed. Journals of the Continental Congress, Volume Ten-1778: January 1May1. (Washington: Government Printing Office, 1908), 10: 83-84. 
mines and refining lead ore.” ${ }^{145}$ Though he did not serve on the Committee for Foreign Affairs, he nonetheless added his own sentiments to their original resolution and presented his findings to the congress.

Henry Laurens, dedicated to the cause of American independence, stepped beyond the limited scope of his political authority, making valuable contributions to the resolutions of the Continental Congress. However, the voluminous correspondence that was required for his position afforded him little time to rest. Another example of this came shortly after he assumed the presidency. In November of 1777, Colonel Benjamin Flower, Commissary General of Military Stores, informed Laurens of a serious deficiency in the procedures of congress in relation to the war effort. The colonel alerted the president that several dozen important commissary positions had not been filled, despite his continued insistence. Laurens immediately went to the floor with these concerns. The resolution providing for these commissions had been passed by the congress in September of 1777. However, due to the confusion that had accompanied the evacuation from Philadelphia, no action had been taken. Bringing the Commissary General's letter directly to the congress, the president urged an immediate response. The commissions were filled and Laurens sent an immediate response to Colonel Flower. ${ }^{146}$

On November 30, 1777, President Laurens wrote to Lieutenant Colonel John Laurens that "the last 48 hours, have been almost wholly employed at this table and in Congress.” "In that time,” Laurens continued, "I have had about 7 hours sleep.” Less than one month into his new position, Laurens was overwhelmed. The information that was made available to him began to weigh heavily on his mind. As the President of

\footnotetext{
${ }^{145}$ Ford, JCC, 9: 884.

${ }^{146}$ Ford, JCC, 10: 890-891.
} 
Congress, Laurens was privy to reports from all departments of the war. One report from General Washington warned of the possibility of General Howe taking the city of York and seizing the entire government. Although this report was never verified, and proved to be idle speculation, such fears existed and gave the president several sleepless nights. ${ }^{147}$ In this same letter, Laurens lamented the deplorable state of the Continental Congress and the severe lack of ready funds to supply the army. After a thorough investigation, Laurens discovered that the biggest problem resulted from the many commissions promised by Silas Deane to foreign officers during his time in Paris. It was no wonder that the Continental Congress could not keep the army supplied, when it had already bestowed “money out by millions to particular persons” to satisfy these promises. ${ }^{148}$ Recognizing that congress could not continue to support the hordes of French soldiers who were now entreating congress for their promised commissions, Laurens sent letters to the states requesting funds and supplies for the Continental Army as a means of lessening the burden faced by the general government. Laurens also entreated the states to find places for these men within their militia units. Again, not wishing to alienate the French and lose the possibility of an alliance with France, Laurens sought a means to placate these individuals. ${ }^{149}$

All of these factors led Henry Laurens to worry about the future of America. His strenuous efforts to keep up with the volume of correspondence between the congress and the state governments weakened his health and he was stricken with a severe case of gout in December of $1777 . .^{150}$ Though he never doubted that the American cause would

\footnotetext{
147 HL to John Laurens, November 30, 1777, Papers. Chesnutt, 12: 111.

148 Ibid, 12: 112.

149 HL to John Lewis Gervais, November 18, 1777, Papers. Chesnutt, 12: 72-73.

150 HL to Congress, Papers. Chesnutt, 12: 140.
} 
succeed, he feared the ravages of the winter to come and the state of affairs of the general government in York.

Another concern that Laurens faced was the rise in profiteering among merchants within the United States and the sluggish nature of the individual state governments in responding to such actions. When goods purchased in Massachusetts by the Continental Congress through Deputy Clothier General Samuel Otis were not delivered, Laurens and the congress took immediate action. ${ }^{151}$ In a letter to the Massachusetts Assembly, Laurens voiced the "inexpressible concern" of the government towards these merchants who had refused to accept the credit of the Continental Congress. Laurens, though speaking for the general government, added his own sentiments and passionate expression to this letter in an effort to arouse a sense of duty to the cause in the members of the assembly. "If the several governments do not speedily exert their authority to effectually suppress such unheard of extortion,” he stated, condemning the merchants who did not fulfill their contractual obligations, "it will unquestionably issue, and at no very distant period too, in the destruction of the liberties of this continent.”152

Another important task that Henry Laurens was vested with was maintaining the positive relationship between the Continental Congress and the foreign officers in service to the United States. In this, Henry Laurens the diplomat comes into prominence. The most important ally, of course, was France. Aside from informing General Washington and the regional commanders of the Continental Army of the disposition of supplies and money, Laurens also sent letters to Lafayette outlining the government's progress. To ensure the safe arrival of his correspondence, Laurens informed the Marquis that he

151 Ford, JCC,10: 1072.

152 HL to the Speaker of the Massachusetts Assembly, December 31, 1777, Papers. 12: 228. 
always sent out six copies of his letters during war, a habit that he suggested that the Marquis adopt when communicating with his contacts in France. ${ }^{153}$

In a letter dated December 20, 1777, Laurens informed Lafayette that John Adams had been appointed one of the American Commissioners to the court of France and asked the Marquis to introduce Adams, "to the countenance of your noble friends in France.” Laurens realized Adams could make vital political and financial contacts within the French nobility so he acted independently of the Continental Congress. ${ }^{154}$ Relying on his friendship with the Marquis helped Laurens to achieve otherwise unattainable ends.

Another aspect of his position allowed Laurens to underscore resolutions made by the Continental Congress with respect to the individual states. Though much of what was transmitted to the state governments was included in official dispatches, Laurens sent personal letters to the leadership of the states pointing out important information in these dispatches. Some of these acts of congress were only briefly discussed in the official dispatches, yet were promoted by Laurens as priorities for the consideration of the state legislatures. Most of the resolutions that Laurens underscored as priorities dealt with supplies and money for the Continental Army. ${ }^{155}$

To say that Laurens was a dedicated public servant does not begin to describe the diligence with which he embraced his responsibilities. Despite the deleterious effect that the presidency had on his health, Laurens worked constantly to communicate the desires of Congress to the state governments and the commanders of the Continental Army. Writing late into the night and at the earliest light of the morning, Laurens stressed the

\footnotetext{
153 HL to the Marquis de Lafayette, December 8, 1777, Papers. Chesnutt, 12: 134-135. His correspondence with the Marquis resembles the intimacy of his correspondence with John Laurens--he even went into detail about his affliction with gout.

154 HL to the Marquis de Lafayette, December 20, 1777, Papers. Chesnutt, 12: 164.
} 
importance of each state's participation in the American cause. Despite the pain of his affliction Laurens did not wish to miss the appointed meetings of the congress. He therefore resolved to be carried into sessions when walking proved difficult. ${ }^{156}$

What concerned Laurens most was the fact that General Washington’s forces had recently entered their winter quarters. With the ravages of winter, it became increasingly necessary to seek out new sources of supplies and clothing for the troops. "Had proper diligence been used," he wrote in reference to the sluggish nature through which congress had originally responded, "those who are now naked and perishing in General Washington`s camp might have all been covered in November.”157 His frustrations reached a fevered pitch when winter ravaged the Continental troops encamped at Valley Forge, Pennsylvania. Throughout the country, Continental troops were settling into their winter quarters. From assuming the presidency in November until January of 1778, Laurens received dispatches outlining a shocking lack of supplies and money from New York, Rhode Island, Pennsylvania, and South Carolina.

Writing to Rhode Island Governor Nicholas Cooke, Laurens commented that since Congress had made no response to Cooke's request for provisions for the Continental troops in service to his state, that he would "embrace the earliest proper opening for bringing the State of Rhode Island into view again.”158 Cooke had asked Congress to assist the troops in his state as early as November of 1777 . However, due to the fact that the Congress was acting in the capacity of Quartermaster General, Clothier General and Commissary General, the government could not effectively respond to

${ }^{155}$ Circular to the Speakers, December 23, 1777, Papers. Chesnutt, 12: 186.

${ }^{156}$ HL to John Lewis Gervais, December 30, 1777, Papers. Chesnutt, 12: 220-222.

157 HL to William Livingston, December 30, 1777, Papers. Chesnutt, 12: 227.

${ }^{158}$ HL to Nicholas Cooke, January 3, 1778, Papers. Chesnutt, 12: 240-241. 
Cooke's request when he had made it. Laurens confessed that while this excuse was unfortunate it in no way represented a "neglect” of Rhode Island's demands.

It was at this time that Laurens began to recognize the subtle development of party factions within the Continental Congress. What distressed him most about this issue was the effect that this partisanship had on public policy. Already concerned that the machinations of Silas Deane had contributed to the financial crisis affecting the government, Laurens began to despise the political infighting he witnessed in the Congress. Writing to Jonathan Trumbull in January of 1778, Laurens confessed that the entire American cause was “on the brink of a precipice.” The entities necessary for the sustaining of the army were, "shattered and distracted," with the Continental Congress pressed into acting as Clothier General, Commissary General, and Quartermaster. The purpose of this letter was to entreat Trumbull, who had acted as Commissary General until his resignation in July of 1777 , to return to his position. The failure of his replacement to effectively carry out his responsibilities had caused more problems, not only for the army but within the Continental Congress. ${ }^{159}$

In words appealing to Trumbull's patriotism, and his previous service to the country, Laurens alluded to the thanks of a grateful nation. Moreover, President Laurens acted without the knowledge of the Congress. He acted because he recognized the importance of having a dedicated public servant like Trumbull continue in service to the American cause. Going above the responsibilities vested in him by his position, Laurens recognized the considerable void that Trumbull's absence had caused and acted to prevent the appointment of a less qualified individual to take his place. Trumbull

159 HL to Jonathan Trumbull, January 5, 1778, Papers. Chesnutt, 12: 250-252. 
responded that while he was grateful for the president's comments, his health precluded him from returning to his duties. However, he did make suggestions as to where the congress could look to find food supplies for the Continental Army and lauded the president for his dedication to the cause. ${ }^{160}$

Seeing that the question of a permanent supply line to the Contiental Army would not be easily answered, Henry Laurens called the congress into extra sessions in January of 1778. The continual requests from army commanders represented a grave danger to the success of the military as it faced a harsh winter and Laurens realized that a solution had to be found. ${ }^{161}$ This was the question that the congress would struggle with throughout the remainder of Henry Laurens’ term as president.

Despite his strenuous efforts to keep up with the various supply needs of the army, Laurens began to fear that the entire enterprise was in danger of fragmenting into chaos. In the midst of the pressing financial constraints facing the government, a serious conflict within the Continental Army came to light. In the early weeks of January several letters were forwarded to the president by Lieutenant Colonel John Laurens, who was encamped at Valley Forge with General Washington. These letters contained the complaints and pointed accusations of Major General Thomas Conway against Washington, alluding to the inability of the general to successfully command the army. These letters had originally been sent to Major General Horatio Gates in November of 1777, but they were forwarded to General Washington through Lieutenant Colonel Laurens. What followed next would nearly rend the fabric of the Continental Army. ${ }^{162}$

\footnotetext{
160 Jonathan Trumbull to HL, January 24, 1778, Papers. Chesnutt, 12: \339-340.

161 HL to Members of Congress, January 13, 1778, Papers. Chesnutt, 12: 295.

162 John Laurens to Henry Laurens, January 3, 1778, Papers. Chesnutt, 12: 244.
} 
In his letter, John Laurens informed President Laurens of the "base insult offered to the Commander-in-Chief which will raise your indignation.” The letter, which was obviously never meant to be seen by Washington, called him a weak general who was a danger to the success of the army. Conway even went so far in his letter as to compare General Washington to Frederick the Great of Prussia. The young Laurens severely criticized General Conway, even alluding to his possible cowardice during the American retreat from Germantown. Fearing that the Congress was dividing into factions over Washington and the continuation of his command, John entreats his father to take an active stance against any such divisions. ${ }^{163}$

When the news of this alleged conspiracy reached Laurens, he concealed it from the Congress until he could have time to reflect on the situation. The issue did not fade away as time passed. Protests from other field officers, some of whom were angered at the fact that Conway had been promoted to Inspector General above more promising generals, were sent to members of congress, the Board of War, and even President Laurens. General Washington himself had already noted that Conway's attitude toward him in dispatches was icy and unbecoming an officer. Moreover, the reception of General Conway at Valley Forge indicated that Washington's staff officers were forming their own opinions on the matter. ${ }^{164}$ Conway denied making accusations against Washington. Furthermore, a rift developed between General Washington and General Gates over the Conway letters which also threatened the command structure of the entire Continental Army. ${ }^{165}$

\footnotetext{
163 Ibid, 12: 244-245. Conway was found sleeping in a barn during the battle, but his respite was due to fatigue and not cowardice.

164 George Washington to Henry Laurens, January 2, 1778, Papers. Chesnutt, 12: 293.

165 John Laurens to Henry Laurens, January 3, 1778, Papers. Chesnutt, 12: 244-247.
} 
In a private meeting between General Conway and the president, Conway reiterated his claims of innocence. "General Conway called on me and sat an hour," Laurens wrote to his son on January 25, 1778. At this meeting, Conway "assured me there were no such words in this letter to General Gates as those quoted by the General [Washington]." Concerned over how far the dispute between Washington and Conway would go, Laurens confessed that "this indeed may be called a public affair and I am afraid will become very public.” It was the issue of just how public the dispute would become that worried the president. An internal quarrel within the Continental Army carried with it the potential for disaster. ${ }^{166}$ Once more afflicted with an attack of gout, Laurens was greatly concerned over this “unhappy dispute subsisting between” General Washington and General Conway. Laurens saw such a conflict as a division that could be used by the British to undermine the independence of the thirteen states and fracture the tenuous union between them. ${ }^{167}$

The possibility of divisions within the Continental Congress over public policy disturbed the president greatly. From his first days as a delegate to the congress, Laurens had seen the gradual rise of party factions within the government. In his letter to Commissary General Trumball, the president commented that he had witnessed the divisions over the most minor issue of public policy. "I saw party," he wrote, “and lamented the prospect, every day enlightened me and I soon prognosticated evils which we are now laboring under and which must be conquered...”168 To John Laurens, the president confessed, "the events which I dreaded and in many instances predicted, are

\footnotetext{
166 HL to John Laurens, January 25, 1778, Papers. Chesnutt, 12: 342.

167 HL to Isaac Motte, January 26, 1778, Papers. Chesnutt, 12: 348.

168 HL to Jonathan Trumball, January 5, 1778, Papers. Chesnutt, 12: 251.
} 
now coming to maturity." "I feel for my country," he continued, "I feel for the thirteen infant states.” Vowing to settle the matter with all deliberate speed and to curtail the development of an internal conspiracy against Washington, Laurens concluded "I will attend to all their movements and have set my face against every wicked attempt however specious.” Though there was no public discussion over Washington's command in the congressional records, Laurens noticed the delegates taking sides. While there was not an organized conspiracy to remove Washington, the president was concerned over the potential for a public debate. ${ }^{169}$

The president began his own investigation. ${ }^{170}$ "I have seen the letter," he wrote to Isaac Motte, referring to General Conway‘s statements to General Gates. "It is true General Washington was misinformed," he reported, "the letter does not contain the words which had been reported to him--but ten times worse in every view." ${ }^{\text {171 }}$ Infuriated at being deceived by Conway, Laurens confessed that, "I had, before some late discoveries, entertained a very high opinion of this General.”

To further aggravate the situation, Congress had debated appointing Conway as Lafayette's second in command for a proposed expedition into Canada. ${ }^{172}$ However, when Lafayette had learned of General Conway's comments regarding Washington, he responded that he was displeased with the manner in which the Commander-in-Chief had been insulted. In a letter dated January 26, 1778, Lafayette commented that Conway was "most disagreeable to me and most prejudicial to the cause." Confessing his utmost respect and friendship for General Washington, Lafayette condemned Conway as a

\footnotetext{
169 HL to John Laurens, January 8, 1778, Papers. Chesnutt, 12: 270-271.

170 Ibid, 12: 272.

171 HL to Isaac Motte, January 26, 1778, Papers. Chesnutt, 12: 348.

172 Ford, JCC,9: 986. Proposed by the Board of War in December of 1777 but abandoned in March ,1778.
} 
despicable and wholly contemptible individual who was unworthy of his position in the Continental Army. He furthermore commented that had such an incident occurred in the French army, the individual responsible "would be confined immediately and cashiered by a court martial."173

What had started as an off-hand comment from one field officer to another regarding General Washington, was now a threat to the stability of the army and a matter of great concern to the President of the Continental Congress. Lafayette alluded to the possibility that the French officers in service to the United States would return home should such an insult to Washington go unanswered. ${ }^{174}$ It was the possibility of losing the alliance with France that frightened Laurens the most. Despite the presence of American representatives in the court of France, little progress had been made on that issue. "Has France done one act of kindness towards us but what has been plumply for the promotion of her own interests,” he asked William Livingston. The official dispatches of Benjamin Franklin gave no intimation that the American commissioners were close to a treaty or alliance and Laurens was becoming visibly concerned. The veiled threat of the Marquis de Lafayette to withdraw his support did not inspire confidence in the president and only served to aggravate an already tense situation. ${ }^{175}$

If Lafayette were to leave North America and return to France, it was highly likely that the majority of French officers in service to the United States would accompany him. The ranks of the Continental Army would be depleted and, moreover, the potential alliance with France would never materialize. ${ }^{176}$ Lafayette did not want

\footnotetext{
173 Marquis de Lafayette to Henry Laurens, January 26, 1778, Papers. Chesnutt, 12: 352.

174 Ibid, 12: 352.

175 HL to William Livingston , January 27, 1778, Papers. Chesnutt, 12: 354-358.

176 HL to John Rutledge, January 30, 1778, Papers. Chesnutt, 12: 375-281.
} 
Conway as his second in command and he had made his point clear in subsequent letters to Henry Laurens. On January 31, 1778, rather than merely alluding to the possibility of a French withdrawal, the Marquis directly threatened the President of Congress with his resignation. Laurens kept this information hidden from the Continental Congress and proceeded with his own investigation. ${ }^{177}$

To further complicate matters, on January 26, 1778, a mysterious letter was delivered to the president during a session of the Continental Congress. Delivered by a member of Congress, this letter contained comments about General Washington's command style and the alleged dominance of the government by the military. Declaring that "the hearth was the proper disposition for such records," Laurens concealed the letter from the Congress and read it in private. Seeking to avoid being drawn further into a partisan conflict, the president sent the letter to General Washington for his reflection. He asked the general to keep this communication in confidence as the situation was already growing out of hand. ${ }^{178}$

Speaking with General Gates regarding the letters from Conway, Laurens worked to prevent a further breakdown in the army hierarchy. In a conversation with General Gates, Laurens found him "heartily disposed to a reconciliation” with the Commander-inChief. "I have no doubt," he added, "that the same disposition would upon enquiry be found on the other side.” Hoping that his personal conversations with the key players in this conspiracy would settle the matter, Laurens operated without the assistance of the Continental Congress. Condemning General Conway's statements as “the blackest hypocrisy,” Laurens obtained from Gates sympathy for Washington and a personal vow

177 Marquis de Lafayette, January 31, 1778, Papers. Chesnutt, 12: 387.

${ }^{178}$ HL to George Washington, January 27, 1778, Papers. Chesnutt, 12: 359-362. 
to redeem their relationship. ${ }^{179}$

Having settled the dispute between Gates and Washington, Laurens now moved to reassure Lafayette that the situation was well under control and that no more attempts to impugn the authority of the Commander-in-Chief would prosper. Indeed, his public support of General Washington throughout the Conway dispute worked to prove this end. ${ }^{180}$ Meanwhile, the Marquis was engaged in problems of his own regarding the proposed military expedition into Canada. Facing a severe lack of funds, and no response from the Continental Congress on their availability, Lafayette agreed that the best solution would be to cancel the expedition. He had communicated his decision to the president in a letter dated February 19, $1778{ }^{181}$ In March of 1778, the Continental Congress agreed that the expedition would be futile and it was finally cancelled. ${ }^{182}$ In April of 1778, Thomas Conway expressed his wish to resign his commission as an officer in service to the United States. President Laurens presented the general's request to the congress, and they accepted it without debate. ${ }^{183}$

In a letter to Lafayette, Laurens assured the French noble that he was deserving of his own command and that he should communicate with Washington to secure such a place for him as his service to the cause demanded. The president further ordered $\$ 6,000$ (Continental currency) out of his own funds to pay the Marquis’ expenses back to Valley Forge in compensation for his financial losses during the aborted expedition to Canada. In the postscript of his letter to Lafayette, Laurens also commented that General Gates

179 HL to John Laurens, February 3, 1778, Papers. Chesnutt, 12: 393.

180 HL to the Marquis de Lafayette, March 4, 1778, Papers. Chesnutt, 12: 512.

181 Lafayette to HL, February 19, 1778, Papers. Chesnutt, 12: 468-471.

182 Ford, JCC, 10: 217.

183 Thomas Conway to HL, April 22, 1778, The Papers of Henry Laurens, Volume Thirteen: March 16, 1778-July 6, 1778. David R Chesnutt, ed. 7 vols. (Columbia: University of South Carolina Press, 1992), 13: $169-170$. 
was anxious to find a suitable position for the Marquis within the army. This letter served to reassure the Marquis that the president had successfully dealt with any attempts to undermine the authority of General Washington. It furthermore empowered the Marquis by assuring him that his opinions regarding the conduct of the war were valid and had been taken into consideration. ${ }^{184}$ While Laurens entertained his own opinions of the French government, he did not wish to lose this most valuable ally. Indeed, his actions over the course of the Conway dispute were partially, if not fully, motivated by a desire to maintain peaceful relations with the French government and their most significant representative in the United States.

When Lafayette requested permission from the Congress to return to France for the purpose of furthering diplomatic relations with the French King, Laurens presented his esteem and the thanks of Congress for his service. Laurens also commented that Lafayette would be "held by the good people of these states" in high regard and in recognition for his services "an elegant sword" was to be commissioned and presented to the Marquis by the American representatives in France. ${ }^{185}$

Having successful curtailed any possible conspiracy and, more importantly reassured Lafayette that the government was fully behind General Washington, Laurens had settled a potentially dangerous political question. Should Washington be challenged in his command, the tenuous alliance between France and the American Confederation might die in its infancy. Furthermore, the fracturing of the Continental Army over an interpersonal conflict would have greatly damaged the morale and the legitimacy of the

\footnotetext{
184 HL to the Marquis de Lafayette. March 6, 1778, Papers. Chesnutt, 12: 519-521.

185 HL to the Marquis de Lafayette, October 24, 1778, The Papers of Henry Laurens, Volume Fourteen: July 7, 1778-December 9, 1778. David R Chesnutt, ed. 7 vols. (Columbia: University of South Carolina Press, 1994), 14: 448.
} 
national command structure. In his efforts to prevent such a break down, Laurens proved to be a most capable crisis manager. He used his personal relationship with Lafayette to prevent him from abandoning the war effort. He exercised his authority outside of congress to get to the heart of the matter with the key players in the conspiracy. 


\section{Chapter Three: Atrophy and the French Alliance}

Less than three months into his presidency, Henry Laurens had successfully defended George Washington against an alleged movement to displace him and prevented a breakdown in relations between the United States and France. Laurens redefined his scope of authority without the approval or knowledge of Congress in an effort to clarify his position. In the months that followed the Conway dispute, Laurens had little respite from the problems caused by the revolution. Between February and May of 1778, as attendance to the Congress waned, Henry Laurens came into public view as he pled for the continued support of the individual states. With ratification of a treaty of alliance with France still a pressing concern, Laurens wanted to create a stronger union between the thirteen states by arguing the intrinsic dangers of political leaders vacating their national responsibilities. These were the often overlooked internal political struggles that accompanied the American Revolution.

At the same time he was confronted with the severe lack of funds for the Continental Army and the internal dispute between Washington and Conway, Laurens noticed the shrinking numbers of representatives in Congress. "The house has been reduced to nine states represented in units that we have been stagnant from a want of members," he wrote to John Lewis Gervais in January of 1778 . This was the state of affairs to which the general government had sunk in the months following the evacuation of Congress from Philadelphia. Laurens confessed that had been reduced to idle debate for days at a time due to a severe lack of representation from the states. The political affairs of the nation were ignored, a fact that President Laurens lamented repeatedly in 
his personal correspondence. ${ }^{186}$ Moreover, this deficit generated serious problems for the government, problems that Laurens and the few remaining members of the Continental Congress were forced to contend with on their own. His balancing of these concerns had a continued effect on his personal well being.

In this same letter, Laurens complained of the pitiful state of affairs to which the government had been reduced. Predicting doom and disaster for the general government, not to mention the revolution itself, Laurens encouraged Gervais to send South Carolina politicians to the Continental Congress. ${ }^{187}$ Only this action could prevent the government from further digressing into a state of chaos in the midst of the war. It was his hope to impress upon the leaders of the individual states the need for such an action. To Governor William Livingston of New Jersey, Laurens commented, “our whole system is tottering, and God only knows whether we shall be able to prop it up.”188 Due to the poor representation in Congress, the board of war and the various government departments responsible for distributing supplies to the army were lax in their responsibilities. Laurens now saw to the proper distribution of the necessary supplies, in addition to his presidential responsibilities. The volume of correspondence from the president throughout these months indicates his dedication to the task, and demonstrates just how serious the situation had become. In his letter to Governor Livingston, the president commented that while the members of Congress continued to debate he had expanded his own responsibilities by performing the duties of other officers. ${ }^{189}$

"The powers of Congress fall short of compulsive means," Laurens again wrote to

\footnotetext{
186 HL to John Lewis Gervais, January 30, 1778, Papers. Chesnutt, 12: 225.

187 Ibid,12: 222-226.

188 HL to William Livingston, December 30, 1778, Papers. Chesnutt, 12: 226.

189 Ibid, 12: 227.
} 
Livingston in January of 1778 . The Continental Congress, while a national assembly, did not have the ability to compel the individual states to pursue a course of action. This was the inherent flaw of the American Confederation, in that the national government lacked the power that was necessary to enforce its legislation. In addition, the government now lacked members, which represented a serious problem. "We want of genius for striking out new matter," he continued, "for correcting errors and repressing dangerous appearances.”190 To Rhode Island Governor Nicolas Cooke, Laurens commented that while the Congress was working on settling the issue of supplies and funds for the army, the debates "fall heavily upon a very few members, from 17 to 21 who faithfully attend their duty." Some of the representatives who attended could not act because their individual state constitutions required a minimum of their delegations to be present. Several times, Laurens alludes to the frustration of the Congress over members who attended the regular meetings but could not legally participate. Noting the seriousness of the army's plight, the president informed Governor Cooke that "these circumstances" were the root cause of the sluggish nature of the general government and not an example of purposeful neglect by Congress of national concerns. ${ }^{191}$ However, "the unaccountable deficiencies" in the government were beginning to weigh heavily on President Laurens' mind. Praising those few members who continued to attend the meetings of Congress, Laurens assured the leadership of the several states that the general government was not slipping towards chaos. Even so, he personally feared such an occurrence. ${ }^{192}$

It was the lack of congressional delegates, compounded with the desperate need

\footnotetext{
190 HL to William Livingston, January 27, 1778, Papers. Chesnutt, 12: 356.

191 HL to Nicholas Cooke, January 3, 1778, Papers. Chesnutt, 12: 240-241.

192 HL to William Heath, January 5, 1778, Papers. Chesnutt, 12: 249.
} 
of supplies for the army, that motivated Henry Laurens to call Congress into extra sessions beginning in January of 1778 . To satisfy the pressing needs of the Continental Army, Laurens realized those few members present needed to perform the duties of the entire government. The "urgent and important business, which requires immediate dispatch" that the president spoke of in his letter to the delegates outlined the state of affairs for the government during this time. Laurens recognized the need for the Congress to compensate for the gradual ebbing of its membership by dedicating more hours to the plight of the nation. The scant few remaining delegates, ranging from 17 to 21, and even less at times, whole heartedly agreed. ${ }^{193}$ "There are presently 21 members on the floor," he wrote to New York Governor George Clinton in January of 1778. Of these 21 delegates, Laurens spoke highly of their devotion to the cause. However, "in order to guard against the dispersion of the army, “ he wrote, Congress was forced to act as “Quartermaster General, Clothier General, Commissary General.” Laurens realized that this effort could not be maintained indefinitely. Adding his own sentiments to the letter, Laurens requested that Governor Clinton send “more ample representation from the State of New York" to fill the void within the Continental Congress. In the winter of 1778, New York was represented by only one delegate, William Duer. The rest of that state’s six member delegation had left the capital for public pursuits within New York and throughout the United States. Consequently, New York could contribute little to the sessions of Congress until it had reached its required quorum. Laurens made this fact clear in his letter to the governor. ${ }^{194}$

Laurens reiterated this same request to the government of South Carolina on

${ }^{193}$ HL to the Members of Congress, January 13, 1778, Papers. Chesnutt, 12: 295.

${ }^{194}$ HL to George Clinton, January 14, 1778, Papers. Chesnutt, 12: 298-299. 
January 26, 1778. Even his home state was a contributing factor to this crisis of representation. Poor representation endangered the ability of the Continental Congress to effectively govern the thirteen states. "I hope the states will be roused," Laurens wrote, "[to] fill their representations in Congress with wise and spirited men.” The success of the revolution and the independence of the thirteen colonies depended on this. "If the states do not exert themselves," the president commented, "their Stewards will complete their ruin and disgrace.”195 Laurens saw the lack of representation as a contributing factor to the destruction of the tenuous union of states. Not only could the union suffer from this atrophy, but the very success of the American Revolution.

Laurens realized that the deficiencies within the Congress were affecting every aspect of the war effort. When the president moved to appoint Brigadier Generals within the state of South Carolina, he was vexed to find that once again there were not enough members in attendance to discuss the issue. When he pressed the resolution before those members present, Laurens was informed that "there was no body on the floor to take up and improve the suggestions from the chair., ${ }^{196}$ Angered, the president retired to his study and wrote a frustrated letter to Isaac Motte. "We deserve the evil of this delay," he wrote, "for our shameful and unpardonable delay of filing up our delegacy with sensible vigilant faithful citizens.”197

Thinking of the American image in the courts of Europe, most especially in the court of France, Laurens argued that the revolutionary movement could become a farce. To further compound his anguish, Laurens was aware that certain individuals were

\footnotetext{
195 HL to Isaac Motte, January 26, 1778, Papers. Chesnutt, 12: 344-345.

196 Ibid, 12: 349.

197 Ibid, 12: 349-350.
} 
profiting from the war effort and had set aside funds for themselves while the Continental Army suffered for want of provisions and funds in its winter camp. "Knaves and fools are building enormous estates," he said of the vast corruption among state officials and private individuals who were profiting from the war effort, "sapping the foundations of liberty, virtue, and their country.” To Laurens, these individuals were as greedy as the British Parliament. They were abusing the trust given to them by the American government and providing for their greed. ${ }^{198}$ Realizing the danger of such profiteering, Laurens went to Congress to counteract those responsible.

Reporting this news directly to the Congress, Laurens encouraged the creation of the office of Auditor of Army Accounts, to determine where public money was being used wisely. Recognizing the dire need for such a position, Laurens persuaded Congress to empower the public auditors with the ability to prosecute any individual responsible for the misuse of government funds to the fullest extent of the law. This was the president's most stringent effort to unravel the web of corruption that he noticed spreading throughout the young nation. Laurens further added that any individual guilty of subversion against the United States should be dealt with promptly. The resolution was discussed and approved by the Continental Congress in February of 1778. Though Congress suffered from a lack of membership, those delegates present were rallied by Laurens to take decisive action. Not only did Laurens publicly advocate this position, but he helped to draft the document that created it. ${ }^{199}$

As a result of the creation of this office, several individuals who had misappropriated public funds were brought to justice. Laurens presented this information

\footnotetext{
198 Ibid, 12: 345.

199 Ford, JCC, 10: 131-136.
} 
to the Congress and voted in favor of a full investigation. At one point, an investigation into the actions of the various administrators of the Commissary departments seemed to unmask a high-ranking officer responsible for using public money for his own personal gain. When Colonel Benjamin Flower was accused by his deputy, Cornelius Sweers, of such malfeasance of office, the Congress ordered his immediate arrest. ${ }^{200}$ Though it pained him to see such a dedicated soldier as Colonel Flower named in this investigation, Laurens nonetheless approved of the action. His previous experiences with corruption under the royal government in South Carolina firmed his resolve. Entrusting Colonel Flower to the guardianship of Major General Benedict Arnold, the Congress ordered a further investigation into Sweers' accusations. ${ }^{201}$ When it was determined that Colonel Flower had nothing to do with the misappropriation of public money, and in fact Cornelius Sweers was the responsible party, all charges against the colonel were dropped and his rank and privileges restored. ${ }^{202}$

While Colonel Flower was innocent of any wrongdoing, corruption and general dissention certainly existed within the departments of the government. ${ }^{203}$ With the approval of Congress, Laurens began a long term correspondence with the leadership of the thirteen states to remind state executives of the importance of national unity and adequate representation in Congress. Using the examples of profiteering, Laurens hoped to expose the dangers of a government unable to manage its own affairs. Throughout February and March of 1778, the president sent passionately worded reminders to South

\footnotetext{
200 Worthington C Ford. Journals of the Continental Congress, Volume Eleven: 1778, May2-September1. 37 vols. (Washington: Government Printing Office, 1908), 11: 741.

201 Ford, JCC,11: 748.

202 Ford, JCC, 11: 826.

203 HL to George Washington, May 17, 1778, Papers. Chesnutt, 13: 316-317.
} 
Carolina, Pennsylvania, Delaware, and New York. ${ }^{204}$ This was the only means to impress upon state leaders the importance of having full delegations in attendance. While the orders had come from the Congress, the words and thoughts were his own. Laurens realized the enormity of his task and the importance of a swift response from the states.

To further compound his anguish over the lack of proper representation with the Congress, Laurens was forced to chide one of his colleagues for neglecting his responsibilities. When North Carolina Delegate Thomas Burke refused to attend a session of the Continental Congress in April of 1778, Laurens sent a messenger from the meeting room to Burke's residence in York. Burke refused to appear before the Congress and forced a delay in the day's business. Claiming that only his home state of North Carolina had the authority to command his attendance at congressional meetings, Burke ignored the order of Congress. This response infuriated the president, who dispatched the messenger again to Burke's residence. Laurens and the remaining delegates determined that an official sanction would be the best course of action. Burke was compelled to appear before the Congress on April 24, 1778 and answer for his act of defiance. ${ }^{205}$

The first congressional inquiry into the actions of one of its own members began and ended on that day. After restating his claim that the Congress did not have the authority to compel him to attend its meetings, Burke claimed that he had received no such mandate from the North Carolina Assembly empowering him to return. ${ }^{206}$ When the Congress voted on whether or not to expel Burke, Laurens voted against such an action as detrimental to the general government. The Congress had already lost a significant

\footnotetext{
204 Ford, JCC, 10: 246.

205 Ford, JCC,10: 386.

206 Ibid, 10: 386-389.
} 
portion of its membership and until North Carolina appointed a new delegate, Burke was needed. ${ }^{207}$ Subsequently, the Continental Congress ordered the full record of the proceedings concerning Thomas Burke to be sent to the North Carolina Assembly. ${ }^{208}$ Henry Laurens wrote an attachment to the official message sent by the assembly from York. "I am persuaded it is not the desire of Congress," he wrote to North Carolina Governor Richard Caswell, "to take advantage of Mr. Burke, nor hurt his character by impressions made in his absence on the minds of his fellow citizens...” His intention in calling Burke before the Congress and supporting the motion to censure him was due to the need for every available delegate to perform their duly appointed task. In this letter, Laurens maintained that it was not the result of individual bias or any political fracturing within the general government that had brought about this course of action. It was simply a matter of maintaining a quorum. ${ }^{209}$

Delegate Burke believed his term in the Continental Congress was over, in accordance with the constitution of the state of North Carolina. In his response to Laurens' request that he present himself to the body immediately, Burke informed the president that he had received no orders from North Carolina empowering him to continue to speak for that government. He therefore resolved to quit the house and await further instructions from his home assembly. ${ }^{210}$ While this was the proper thing to do given the protocol of the day, it aggravated an already serious problem. However, President Laurens was concerned over the disturbing inability of the Congress to function without members. Burke was singled out because he was physically in York, but had

\footnotetext{
${ }^{207}$ Notation, Papers. Chesnutt, 13: 214,

208 Ford, JCC, 10: 391.

${ }^{209}$ HL to Richard Caswell, April 27, 1778, Papers. Chesnutt, 13: 197.

210 Thomas Burke to HL. April 28, 1778, Papers. Chesnutt, 13: 214-215.
} 
refused to return to the floor as requested. ${ }^{211}$ As Laurens had commented to Samuel Adams, "Able men are exceedingly necessary in Congress at this time.”212

"All the states have been exceedingly remiss in their respective representations in Congress," the president wrote to Jacob Zahn in April of 1778. "A remiss," he added, "which will cost them millions of dollars, and which had one time exposed our cause to the most imminent danger. ${ }^{\text {"13 }}$ Laurens was certain that if the thirteen states were to work together, militarily as well as politically, that they could drive the British from North America. ${ }^{214}$ Obviously, the president realized that unity was just as important to the success of the cause as a military alliance with France. This was what had motivated Laurens in his tireless efforts throughout the winter months of 1777 and 1778. Slowly, the individual states responded to the president's repeated requests for delegates. Throughout the months of April, May, and June of 1778, the states sent new representatives to fill the vacancies within the Continental Congress. Though the president continued to express his concern over inadequate representation, his efforts over the previous months were beginning to bear fruit. ${ }^{215}$

Having weathered a particularly difficult political quagmire regarding the disputes between Washington, Gates, and Conway, the Congress was engaged in another serious issue that concerned the president. The military and commercial alliance with the government of France played heavily into Henry Laurens’ actions while President of the Continental Congress. Throughout his final months in office, Laurens added the final touches to the alliance and welcomed America's first official diplomatic representative

211 HL to Jacob Christopher Zahn, April 28, 1778, Papers. Chesnutt, 13: 210-211.

212 HL to Samuel Adams, April 26, 1778, Papers. Chesnutt, 13: 189.

213 HL to Christopher Zahn, April 28, 1778, Papers. Chesnutt, 13: 211. 
from another country.

Recognition by a powerful European nation such as France was essential to victory in the American Revolution. Laurens was aware of this even before he began his term as president, and he endeavored to achieve the much desired alliance between France and the United States. During the Conway incident and Laurens’ struggle with congressional atrophy, important steps were taken toward an official alliance with the French government. However, just as the Congress was about to discuss the wording of the alliance, another serious concern came to light.

The main issue facing Henry Laurens and the adoption of a treaty of alliance between France and the United States concerned the possibility of peace overtures from the British government. To accept a military and commercial alliance with the French could close the door on any possible reconciliation between Great Britain and her former colonies. As President of Congress, Laurens had received information that General Sir William Howe had been instructed to make a settlement with the American government in November of 1777 . This news had been delivered to the president through another member of the Congress and presented to the general assembly. A Pennsylvania merchant named John Brown claimed to have escaped occupied Philadelphia with "a verbal message to Congress from General Howe.” Since the message was delivered orally through an intermediary Congress refused to consider it. "Such conduct administers just grounds of suspicion,” the Congress resolved, "that he is employed by the enemy for purposes inimical to these states." ${ }^{\text {216 }}$ Laurens himself found this news to be

${ }^{214}$ HL to James Duane, April 7, 1778, Papers. Chesnutt, 13: 81.

215 Wallace, 288-289.

${ }^{216}$ Ford, JCC, 9: 937-938. 
“mysterious" and did not consider such an offer to carry any serious weight. ${ }^{217}$

Accordingly, the Congress ordered Brown to be arrested and held by the government of Pennsylvania. ${ }^{218}$

The American government, and President Laurens, considered any statements sent through intermediaries regarding the continuation of the war to be specious. "The [British] administration was greatly shocked," Laurens commented to the Marquis de Lafayette, "by the account of Mr. Burgoyne’s surrender, but it does not appear from any hints dropped on their part that they were disposed to terminate their dispute with America."219 "There possibly will be attempts to treat for peace," he continued, "but I do not expect anything substantial to follow, but blows..."220 In this letter, the president warned the Marquis that the "monied people of England" were becoming alarmed at the length of the conflict and had begun to throw their support into the British effort. If this trend were to run unabated, Laurens argued, the future of the revolution would be in greater jeopardy. ${ }^{221}$

The president urged Lafayette to be an advocate for the American cause with his French peers. The fact that Laurens had urged Lafayette to return to Valley Forge to work with Washington after the cancellation of his military expedition into Canada demonstrated his concern to keep the Frenchman true to the cause. ${ }^{222}$

When news arrived of a treaty of alliance between the United States and France, all that Laurens had worked so hard for seemed to pay off. However, the acceptance of

${ }^{217}$ HL to George Washington, November 19, 1777, Papers. Chesnutt, 12: 75-76.

${ }^{218}$ Ford, JCC, 9: 938.

${ }^{219}$ HL to the Marquis de Lafayette, March 24, 1778, Papers. Chesnutt, 13: 29.

${ }^{220}$ Ibid, 13: 29-30.

${ }^{221}$ Ibid, 13: 30.

222 Ibid, 13: 30-31. 
that treaty while considering peace overtures from the British government was a hindrance to an effective alliance. Laurens did not trust the British, and neither did many within the government. In his letters to Lafayette, the president warned of the misleading nature of England's overtures. From May to July of 1778, Laurens balanced overtures from British commissioners and the French alliance he had fought so hard to achieve.

Henry Laurens wanted peace with Great Britain but he wanted it to be on “honorable terms,” meaning the full recognition of American independence. ${ }^{223}$ The stunning American victory over the forces of General Burgoyne at Saratoga led the British government to reconsider its position on America. To add further concern, news that the American government was close to a treaty of alliance with France forced Prime Minister Lord Frederick North to reconsider his position in December of 1777. In a speech before Parliament, Lord North offered the United States a repeal of all taxes and acts that had caused the Americans to rebel against that crown. ${ }^{224}$ He further promised the states freedom to elect their own governors and civil administrators, as well as the power to determine their own political futures. North even promised to recognize the legitimacy of the Continental Congress as a governing body. This decision was passed through the Parliament at the same time the treaty of alliance with France was being signed by American plenipotentiaries in Paris. ${ }^{225}$ While this news was what Henry Laurens had always wanted, he viewed the Prime Minister's decision with skepticism. “Admitting this suspicion to be grounded in experience,” Laurens wrote in April of 1778,

\footnotetext{
223 HL to John Laurens, April 28, 1778, Papers. Chesnutt, 13: 208-209.

224 Wallace, 296.

225 Gregory D. Massey, John Laurens and the American Revolution. (Columbia: University of South Carolina Press, 2000), 105.
} 
“we ought to be ready and early with a formidable army in the field."226

The Marquis de Lafayette had warned Laurens that Lord North had no intention of allowing America to be free of British rule. Rather, the Marquis surmised that North's attempt at reconciliation was an effort to further divide the government. ${ }^{227}$ Thinking the peace overtures to be a ploy to destroy the union, Laurens advocated a unified, well prepared military for the coming campaign season. Regarding the peace proposals from Lord North, the president concluded that Britain's overtures were meant to confuse the Congress while the new British commander, Sir Henry Clinton, prepared to break the back of the Continental Army. The movements of General Clinton greatly concerned the board of war, General Washington, and President Laurens. ${ }^{228}$

France and England raced to present their case to the Americans. Great Britain wanted to prevent the Continental Congress from approving a treaty between the United States and France. A commission headed by the Earl of Carlisle was appointed in February of 1778 and sent to the United States. This commission was empowered to treat with the Continental Congress and reach a settlement regarding the conflict. ${ }^{229}$ At the same time, the treaty with France was on its way to York for approval. "If war is declared between France and England,” Laurens confessed, “the British troops may be wanted for defending their islands.” In that case, he argued, the military situation in America would improve for the states. The intrinsic benefit of the French alliance, according to Laurens, would be to force Britain to defend the isles. Personally, the thought of continued warfare concerned the president greatly. Having witnessed first

\footnotetext{
226 HL to John Penn, April 24, 1778, Papers. Chesnutt, 13: 176.

227 Lafayette to HL, January 5, 1778, Papers. Chesnutt, 12: 254.

${ }^{228}$ HL to Jacob Christopher Zahn, April 28, 1778, Papers. Chesnutt, 13: 212.

229 Ibid, 13: 213.
} 
hand the dangers of such conflicts, Laurens was in no way eager to see England ravaged by invasion. ${ }^{230}$

On January 13, 1778, the treaty of Amity and Commerce was signed in Paris between the United States and France. The Treaty of Alliance and an additional document, known as the Act Separate and Secret, was signed in Paris on February 6, 1778. These documents guaranteed military assistance to the United States in her war with Great Britain and allowed for the continuation of friendly relations between the United States and the government of France. In the preamble, King Louis XVI promised to recognize the United States as a favored nation. The treaties finally arrived at York on May 2, 1778 and the Continental Congress immediately considered them. ${ }^{231}$ With regard to the promises made by the French and the stipulations of the treaties, Laurens commented “'tis very well.,"232

While Congress began considering the treaties from Paris, the British peace commission arrived in the city of Philadelphia in April of 1778. General Sir Henry Clinton had ordered the evacuation of the city. The British military was engaged in a general withdrawal at the same time the peace commissioners arrived to begin their meetings with the American government. ${ }^{233}$ “Poor old England,” Laurens wrote in May of 1778 , "she is said to be in great distress and I believe it." ${ }^{\text {"34 }}$

With the president encouraging the adoption of the treaties, the Continental Congress quickly ratified the alliance on May 4, 1778. ${ }^{235}$ A great weight had been lifted

${ }^{230}$ HL to George Galphin, May 1, 1778, Papers. Chesnutt, 13: 225.

${ }^{231}$ Ford, JCC, 11: 418.

${ }^{232}$ HL to John Lewis Gervais, May 3, 1778, Papers. Chesnutt, 13: 241.

${ }^{233}$ Wallace, 296.

${ }^{234}$ HL to John Laurens, May 3, 1778, Papers. Chesnutt, 13: 244.

235 Ford, JCC, 11: 463. 
from the shoulders of Henry Laurens. With recognition of America as an independent nation by the French government came military and financial assistance, plus the promise of equal assistance from nations like Spain and Prussia. Regarding the arrival of the British peace commission, Laurens felt that news of a treaty with France would "oblige them to shape a new course.” Writing to General Washington in May of 1778, the president stated that "the people in general had very sensibly felt the weight of the war, were ardently desirous of peace and anxious lest Congress should reject the intended propositions.” Having received news from several individuals with whom he had dealt in the mercantile industry, Laurens recognized a distinct change in the perception of the business elite of England regarding the war. Though not representing the sentiments of the general populace, these individuals were growing concerned. ${ }^{236}$

However, Laurens also realized that the war would not end quickly. "Britain will not be hummed by a stroke of policy,” he wrote to Baron von Steuben, “... a powerful army in our own fields may, should I say, will, be the only means of securing an honorable peace.”237 The die had been cast and the president realized that there would be no turning back; not for the United States and most definitely not for Great Britain.

While Laurens worked to publicize the alliance between the United States and France he also sought to conceal the news of the British peace commission. He even encouraged Congress not to appoint a delegation to meet with the British commission, as individuals could not properly represent the interests of the entire government and that British delegates could no doubt use that to their advantage. ${ }^{238}$ Realizing the dangers of

${ }^{236}$ HL to George Washington, May 5, 1778, Papers. Chesnutt, 13: 256.

237 HL to Baron von Steuben, May 11, 1778, Papers. Chesnutt, 13: 290.

238 HL to Rawlins Lowndes, May 1, 1778, Papers. Chesnutt, 13: 225-231. 
acknowledging the British peace overtures, Laurens and the rest of the Congress stressed the importance of the French alliance over any offers made by Great Britain. Had these offers been made at the start of hostilities, it is possible that the American government would have been more receptive. It was too late now, especially for Henry Laurens. ${ }^{239}$

The business of government continued as Laurens prepared to receive the official representative from France. In the meantime, Benjamin Franklin had been officially presented to the court of King Louis XVI and accorded all the honors of a formal ambassador. The official exchange of representatives gave the assent to the recognition of the United States as a sovereign nation by her first military ally. At this point, Laurens resolved that any agreement reached between the United States and Great Britain would occur only when the latter recognized the sovereign status of the United States. In his congressional role, Laurens favored a stern resistance to any attempts at negotiation that did not recognize these principals. The door of reconciliation that the president had once referred to had been closed. It was now essential for the belligerents to treat one another as enemies. Great Britain would now have to reach a settlement with citizens of a new nation and not subjects engaged in a rebellion. ${ }^{240}$

“There may be an arduous work to perform,” Laurens wrote regarding the potential for disaster should France and her allies not engage England, "I perceive a long train of direful consequences to America.”241 While he waited to hear from the British peace commission, now settling in Philadelphia, Laurens dedicated his efforts to

\footnotetext{
239 HL to Baron von Steuben, May 11, 1778, Papers. Chesnutt, 13: 291.

240 HL to Louis Duportail, May 20, 1778, Papers. Chesnutt, 13: 335.

241 Ibid, 13: 340.
} 
reforming the Continental Army and preparing for the next stage of the conflict. ${ }^{242}$ Maintaining his allegiance to the French alliance also benefited Laurens in unexpected ways. Though he recognized the importance of commercial and military treaties with other European nations, his main concern was securing the treaty with France. As a result of the machinations of Commissioners Silas Deane, John Adams and Benjamin Franklin, Congress now had the potential to negotiate treaties with Holland, Denmark, Sweden, and possibly Russia. ${ }^{243}$

In response to General Sir Henry Clinton’s withdrawal from Philadelphia and his repeated insistence on a meeting with Congress to discuss an end to the hostilities, Laurens remained firm. "Be assured sir," he argued, "when the King of Great Britain shall be seriously disposed to put an end to the unprovoked and cruel war waged against the United States, Congress will readily attend to such terms of peace.”244 The fact that Clinton had decided to abandon Philadelphia and remove his forces from the vicinity concerned the president greatly. "The idea of the enemy’s intended abandonment of Philadelphia, pervades every mind,” he wrote to John Laurens, “I am very certain our cause suffers greatly from the general belief of an event being at hand.” The event that the president feared concerned the unseen movements of Clinton's forces once they had withdrawn from Philadelphia. General Washington’s army was still not up to full strength and as yet no news had been heard from France regarding a military action against Great Britain. ${ }^{245}$

At the height of this concern, the president received official notification from the

\footnotetext{
${ }^{242}$ HL to Baron von Steuben, May 25, 1778, Papers. Chesnutt, 13: 340.

${ }^{243}$ HL to John Rutledge, June 3, 1778, Papers. Chesnutt, 13: 391.

244 HL to Sir Henry Clinton, June 6, 1778, Papers. Chesnutt, 13: 410.

245 HL to John Laurens, June 7, 1778, Papers. Chesnutt, 13: 414.
} 
British peace commission regarding their offers to the government of the United States. Consisting of Frederick, Earl of Carlisle, George Johnston, and William Eden, this commission offered all the privileges authorized by Lord North and the Parliament. However, the commissioners did not recognize the independent status of the United States. ${ }^{246}$ The commission observed that America was under "the insidious interposition of a power, which has from the first settlement of these colonies been actuated with enmity to both of us."247

In response to this letter, Laurens reminded the commissioners that the decision to end the war was in the hands of the British. "You are undoubtedly acquainted with the only terms upon which Congress can treat," he wrote to George Johnstone. "Permit me to add," he continued, "the true interest of Great Britain in the present advance of the contest will be found in confirming our independence.” Plainly stating the case, the president concluded his letter with a firm reminder that no communications from the British government would be considered unless the independent status of the United States were fully recognized. This right of sovereignty included the right to conduct peace negotiations on an equal footing with Great Britain and to negotiate treaties with allies. $^{248}$

When another letter from the British peace commission arrived in June of 1778, the president immediately put it forward for the consideration of Congress. They resolved that since the letter contained defamatory statements about France, the

246 Carlisle Commission to HL, June 9, 1778, Papers. Chesnutt, 13: 425.

247 Ibid, 13: 425-426.

248 HL to George Johnstone, June 14, 1778, Papers. Chesnutt, 13: 456. 
commissioners were not serious in their diplomatic efforts. ${ }^{249}$ America was moving away from Great Britain, to secure an independent future for itself. By refusing to negotiate with the peace commissioners, Laurens was advocating the official national policy of the United States. Though the commission seemed to be offering a great deal, it had not recognized the distinct national entity that had emerged in North America. Henry Laurens had, and although not originally a proponent of independence he altered his views. A resolution by Congress, signed by President Laurens, informed the British commission that the states will "be ready to enter upon the consideration of a Treaty of Peace and Commerce, not inconsistent with Treaties already subsisting, when the King of Great Britain shall demonstrate a sincere disposition for that purpose.” The British commission had erred when they supposed "the people of these states to be subjects of the crown of Great Britain,” rather than citizens of a free nation. ${ }^{250}$

The Congress opposed meeting the representatives of Great Britain. The failure to recognize American independence was a vital obstruction to the peace process. Laurens advocated a firm stance against the peace commissioners in light of the treaty with France and the potential for absolute victory. Had the Continental Congress accepted the terms of the British peace commission they would meet on an equal footing. The commissioners addressed the Congress as the governing body of the United States, but only as a provincial assembly whose authority was derived from the King of Great Britain. Outraged at the disparaging remarks made by the peace commission towards the government of France, Laurens remarked that while the commission had offered nominal self-determination to the United States, they had given no intimation of American

${ }^{249}$ Ford, JCC, 11: 605-606.

${ }^{250}$ HL to the Carlisle Commission, June 17, 1778, Papers. Chesnutt, 13: 470-471. 
sovereignty. "If all the fine things now offered had been tendered some time ago," Laurens wrote to General Horatio Gates, "there can be no doubt but that the people of America would joyfully have embraced the proposition.” Now, however, "what answer can be given but that which was rendered to foolish virgins--'the door is shut.'”251

America's destiny was now in the hands of the French, or at least for the moment it was dependent on the assistance of the French government. Henry Laurens was well aware of the importance of a commercial and military alliance with France. Having fought for it throughout his presidency, the fulfillment of that desire did not cause him to become lax in his duty to the nation. As President of Congress, Laurens realized the importance of balancing his personal feelings with the will of the government. While he did not support the overtures of the British peace commission, he did not agree with congressional policy regarding any correspondence from the commission. In an effort to determine the legitimacy of the commissions proposals, and perhaps to determine what inducement were offered to members, Congress resolved to make public all letters from the British peace commission to its members. Henry Laurens objected to this on the principal that those letters "were not intended for the public eye."252

It was the issue of public perception that concerned the president the most during this time. Congress was considering the Articles of Confederation for several months. Also, with the evacuation of Philadelphia, Laurens was uncertain of the movements of the British army in North America. ${ }^{253}$ However, with the British withdrawal from Philadelphia, the Continental Congress was able to return to its former home. "Congress

${ }^{251}$ HL to Horatio Gates, June 17, 1778, Papers. Chesnutt, 13: 472-473.

${ }^{252}$ HL to Horatio Gates, June 19, 1778, Papers. Chesnutt, 13: 491.

${ }^{253}$ HL to Rawlins Lowndes, June 23, 1778, Papers. Chesnutt, 13: 507-508. 
will adjourn this morning to Philadelphia,” Laurens wrote to Rawlins Lowndes, "I have many things to day and to hear in a short space of time.”254

The American victory over the British at Monmouth, New Jersey, in June of 1778 afforded Laurens the opportunity to celebrate a fortunate turn of luck for the United States. As he settled into his new quarters in Philadelphia, Laurens was able to reflect on the changing situation for the United States. This victory was another cause for celebration, the deliverance of Washington and a significant portion of his army from what Laurens had called a "snare" coincided with the news of the much coveted French alliance. The efforts of the British peace commission to dissuade Laurens and Congress from allying with France had failed. "I rejoice at the late happy event," the president wrote to John Laurens. ${ }^{255}$ Informing Congress of the happy news, Laurens expressed his gratitude to General Washington and the army. ${ }^{256}$ Congress subsequently resolved to thank Washington "for his distinguished exertions in forming the order of battle” in this significant victory. ${ }^{257}$

With France firmly secured as an ally, Laurens confronted the British peace commission with a renewed resolve. He successfully balanced the offers of the British representatives with the will of Congress and enacted the alliance that he had fought so hard to attain. Claiming the promises made by the British commission had come too late to be considered valid, Laurens was able to firm up the resolve of his congressional colleagues. He had reached a stage in his own ideological evolution where he could

${ }^{254}$ HL to Rawlins Lowndes, Jane 27, 1778, Papers. Chesnutt, 13: 521.

255 HL to John Laurens, July 6, 1778, Papers, Volume Thirteen. Chesnutt, 549.

${ }^{256}$ HL to George Washington, July 7, 1778, The Papers of Henry Laurens, Volume Fourteen: July 7, 1778-Dece,ber 9, 1778. David R Chesnutt, ed. 7 vols. (Columbia: University of South Carolina Press, 1994), 1.

257 JCC, Volume Eleven. Ford, 673. 
dismiss such overtures and concentrate his energies on stimulating America's new relationship with France. 


\section{Chapter Four: Foreign and Domestic Affairs}

Henry Laurens had already established himself as a dedicated advocate for the American cause well before he assumed the presidency of Congress in November of 1777. Through his efforts to entreat the states to adhere to the resolutions of the Continental Congress, Laurens performed an essential diplomatic service to the nation. This much is evident in the correspondence with the leaders of the individual state governments throughout his presidency. He was also vested with the responsibility of maintaining the cordial relationship between the United States and France. For this to succeed, military as well as diplomatic cooperation between the two nations was required. Henry Laurens was the conduit through which this cooperation would travel. However, as he would soon discover, maintaining the alliance with France was far more difficult than achieving it.

In the winter of 1778, Laurens confronted a set of conflicts that resulted from the much coveted alliance with France. With the resources of the national government already taxed to the limit, Laurens was faced with renewed proposals from America's ally to undertake costly expeditions into British controlled territory in East Florida and Canada. He faced these challenges with a mixture of determination to maintain the alliance and a firm resolve not to allow America’s concerns to be rendered secondary to those of the powers of Europe. The remaining months of his presidency found Laurens still arguing against the British peace commission while encouraging the states to cooperate with the wishes of the Continental Congress.

The American Confederation as it existed in 1778 did not give the federal government the broad powers that the government has at present. This was an evolution 
that came only after the flaws in the confederation had been scrutinized. While the Continental Congress was a national legislature, it did not have the power to govern the states. Its main purpose was to create and sustain a common defense against the military power of Great Britain. At this time, the United States was a collective union of sovereign political entities. As a result of that belief, Henry Laurens had to impress upon the states the need to cooperate with Congress.

Laurens could not simply order the government of New York or his home state of South Carolina to adhere to the wishes of Congress. Moreover, the Congress lacked the necessary powers to enforce its legislation without the assent of the individual states. However, as a mediator, the president was able to persuade the states to take actions in accordance with the will of the general government. Laurens excelled at the often vexing art of inter-state diplomatic relations, especially when the greater purpose of the nation's survival was at stake.

When the state delegates failed to appear at session of the Congress, Laurens had appealed to the individual state leaders. Not only did he warn of the fall of the entire American Confederation, but of the more immediate threat to their homes, should the British prevail. How could a state not send its delegates to Congress when that state's own interests were at stake. He even chastised his own state for not sending a full delegation to Congress. ${ }^{258}$ When rampant profiteering among the merchants of Massachusetts was revealed, the president appealed to the Massachusetts Assembly, appealing to their sense of responsibility. He asked Massachusetts to enact legislation

${ }^{258}$ HL to John Lewis Gervais, December 30, 1778, Papers. Chesnutt, 12: 220-226. 
that would make it illegal to profiteer from the war effort. ${ }^{259}$

In an effort to curtail the financial crisis that had brought the Continental Army to its knees, the Congress had agreed on a tax for the individual states. This tax, which would help with the massive financial burden faced by the Congress, was meant to raise \$5 million over a year’s time. In November of 1777, Congress debated the issue and after much revision the resolution was passed on November 22, $1777 .^{260}$ The records of the Continental Congress credit Henry Laurens with a significant portion revising much of the wording of the tax resolution. Laurens altered the original document to make it sound less like a tax and more like a request for additional funding, with the promise to provide suitable recompense to the states over time. His explanation to the individual states stressed the importance of raising this money to provide clothing and supplies to the Continental Army during its winter camp at Valley Forge. ${ }^{261}$

From his first glimpse at the workings of the national assembly, Laurens realized that if America were to endure, the states would have to act like a nation and cooperate on the issues that were important to the whole. A plan of union was the key steppingstone for the building of that nation. When the Congress began considering the Articles of Confederation during his first weeks as a delegate, Laurens became vexed at just how difficult the process had become. "I think I have been instrumental in averting two pernicious schemes," he wrote in September of 1777 regarding the debates over the issues of taxation and the proportion of a state's representation in Congress. ${ }^{262}$ Shortly before the evacuation of Congress from Philadelphia in 1777, Laurens noted that despite

${ }^{259}$ HL to the Speaker of the Massachusetts Assembly, December 31, 1778, Papers. Chesnutt, 12: 228229.

${ }^{260}$ Ford, JCC, 9: 946-947.

${ }^{261}$ Ford, JCC, 9: 955-958. 
the crisis atmosphere, the delegates continued to debate every word of the proposed articles. "Fright," he commented, “works lunacy.” Laurens noticed that despite the crisis atmosphere of the moment the debates still continued. ${ }^{263}$

When Congress began to discuss a system for taxing the individual states as a means of gaining additional revenue, Laurens commented that while "two days have been amused in conning it, some sensible things have been said, and as much nonsense as ever I heard in so short a space.” Despite all of his concern over the confusion caused by the intense debate among the members of Congress, Laurens advocated a compromise over a stalemate. As always with the debates of Congress, Laurens sought to avoid becoming involved in sectional disputes. His intense dislike for factions motivated his efforts to play the part of mediator. Although at times he did take sides on an issue, it was only after serious consideration of the facts. ${ }^{264}$ The adoption of the Articles of Confederation represented a great leap forward in the process of building an independent nation. As Laurens had noted during the debates over the articles, the ratification process required its own special skill to convince the states to accept the final document. ${ }^{265}$

Adopted by the Continental Congress in November of 1777, the Articles of Confederation were sent to the individual states for their consideration. ${ }^{266}$ "These papers,” Laurens wrote, "so expressive of the meaning and good views of Congress require no attempt to a more minute detail of their several contents.” It was Laurens’ hope that the articles would be quickly reviewed and approved by the individual states. ${ }^{267}$

\footnotetext{
262 HL to John Lewis Gervais, September 5, 1777, Papers. Chesnutt, 11: 486.

263 HL to John Lewis Gervais, September 18, 1777, Papers. Chesnutt, 11: 528.

264 HL to John Laurens, October 10, 1777, Papers. Chesnutt, 11: 550.

265 Ibid, 11: 550.

266 Circular to the States, November 28, 1777, Papers. Chesnutt, 12: 104-105.

267 Ibid, 12: 105.
} 
However, Laurens did understand the necessity of a continual review of the articles, due to the hasty nature in which they had been approved. The building of a nation was not a feat that could not be accomplished in the period of a few months, especially in the midst of a war for that nation's survival. While he commented that the articles were not a perfect plan, he wanted them ratified by the states. Discussion and revision could follow, if necessary. He was almost certain that they would need to be revised once the military crisis had concluded. ${ }^{268}$

Between March and July of 1778, various amendments and substitutions to the articles were proposed by the individual state delegations. Congress continued to revise and debate the Articles of Confederation throughout Laurens' term as president. ${ }^{269}$ When the final copy of the articles had been approved by the Continental Congress in June of 1778, Laurens hoped to have it signed by the end of the month. However, due to a series of printing mistakes, the document could not be signed before Congress left York and returned to Philadelphia. When Congress reconvened in Philadelphia in July of 1778, the Articles of Confederation were three states short of being duly ratified. The three states which had not approved of the articles were Delaware, Maryland, and New Jersey. North Carolina and Georgia had approved, but their delegations were not present at this meeting of Congress and therefore could not give their assent. ${ }^{270}$ "Congress intent upon the present and future security of these United States has never ceased to consider a Confederacy as the great principal of union,” Laurens wrote to the leaders of Delaware, Maryland, and New Jersey. He urged the leadership of these states to consider the future

\footnotetext{
268 HL to the John Rutledge, December 1, 1777, Papers. Chesnutt, 12: 115.

269 Ford, JCC, 9: 880, 885, 887-888.

270 Edmund Cody Burnett, The Continental Congress. (New York: The MacMillan Company, 1941 ), 344.
} 
security of the nation over any semantic disputes that might arise from the articles. ${ }^{271}$ The Articles of Confederation were not finally ratified by the Continental Congress until March of 1781, after years of debate over the land boundaries of the states. ${ }^{272}$

While Laurens was often perplexed by the divergent natures of the individual state governments, especially considering the importance of unity at a time of crisis, he proved himself to be adept at rallying them to the cause. He successfully balanced the interests of the individual states with the concerns of the national government. He was able to provide firm guidance without actually possessing the power to compel the states to pursue a course of action.

Laurens was also quite adept at maintaining friendly personal relationships with powerful European nobles, such as the young Marquis de Lafayette. The alliance with France would not have materialized had Lafayette lost faith in Henry Laurens and his abilities to bring reason and firm judgment to the government, particularly during the Conway dispute. Furthermore, had Laurens not exerted every effort to placate the young Marquis regarding the alleged conspiracy against General Washington and Lafayette’s failed mission into Canada, he would never have gained the young Frenchman's trust. While the Conway-Washington dispute is one of the few instances where Laurens demonstrates partisan sentiments, his actions were based not only on his feelings for Washington, but out of concern for the stability of the Continental Army and the success of the French alliance.

It was after the military and commercial alliance with France had been duly

271 Circular to the States, July 10, 1778, Papers. Chesnutt, 14: 17. Though a congressional committee actually composed this letter, Laurens was a party to the wording of it.

${ }^{272}$ Burnett, 345-346. 
ratified by the American Congress that Laurens expanded his diplomatic role. As attaining this alliance was essential to the success of the American Revolution, maintaining that alliance was equally important. Before the ink had dried on the official documents that certified the alliance, the Congress began to make plans to receive the emissary from France, Conrad-Alexandre Gerard. Henry Laurens played an important role in the establishment of the official exchange of representatives between the allies. His interactions with Gerard allowed Laurens to learn more of French intentions in America once the war had concluded.

Gerard had been dispatched by the court of France to represent the interests of his government in the United States. Accompanying him on his journey to America was a squadron of warships that had been dispatched to protect the beleaguered coastline of the United States. Aboard the French vessel Lanquedoc, Vice-Admiral Count Charles-Henri d'Estaing informed the president, "I have the honor sir to remit to your excellency [a] copy of my credential letter."273 Count d'Estaing headed a fleet of 14 warships and five frigates, which had been sent at the behest of the French government and at the urging of the American Minister Plenipotentiary in Paris, Benjamin Franklin. ${ }^{274}$

The count also informed Laurens that "a minister who has been so happy as to have had the indelible glory of signing a treaty which unites two powers whose interests are so intimately connected," would be following his arrival. The count was referring to the imminent arrival of Gerard, who was on board the French fleet. ${ }^{275}$ Writing to North Carolina Governor Richard Caswell, President Laurens urged him "to pursue the most

\footnotetext{
273 Count d'Estaing to HL, July 8, 1778, Papers. Chesnutt, 14: 5.

274 Ibid, 14: 5, notation.

275 Ibid, 14: 6.
} 
effectual measures to apprise the commander of the French squadron, Le Compte d'Estaing, of any English ships of war which may come into any of the harbors or inlets of the state of North Carolina.” The president further urged Governor Caswell to "accommodate the squadron or any of the ships of our ally the King of France with proper pilots," for navigating American rivers, "if required.”276 The moment that Henry Laurens had hoped for had arrived. France was sending military assistance to the United States to aid in its struggle for independence. Congress followed Laurens' suggestion in July of 1778, and ordered the Commander-in-Chief and the American military to cooperate with d'Estaing. ${ }^{277}$

With the arrival of French military assistance, the English view of the war in America began to change. At the beginning of July, Laurens had been made aware of a political upheaval within Great Britain. According to the news articles, published in England in April of 1778, the British Parliament had discussed the idea of authorizing American independence as a condition for negotiation. Laurens noted that "the whole nation" had entered a period of "great distraction."278 To the Count d'Estaing, President Laurens forwarded the response of the Continental Congress to the repeated letters from the British peace commission. He took this action as a sign that America was firm in its devotion to the alliance with France. He also urged d'Estaing "to open a communication with General Washington” in order that the French and American forces might cooperate in their military endeavors against "our common enemy.”279 To Washington, the president remarked, "it is unnecessary to intimate to your excellency the propriety of

\footnotetext{
${ }^{276}$ HL to Richard Caswell, July 9, 1778, Papers. Chesnutt, 14: 11.

277 Ford, JCC, 11: 690-691.

${ }^{278}$ HL to Richard Caswell, July 9, 1778, Papers. 14:12.

${ }^{279}$ HL to the Count d'Estaing, July 10, 1778, Papers. Chesnutt, 14:13.
} 
opening and keeping up a correspondence with Admiral Count d'Estaing," to further that purpose. ${ }^{280}$ An official resolution reiterating this request was written by a committee of the Congress and sent to Washington on July 11, $1778{ }^{281}$

Laurens’ diplomatic efforts did not extend solely to inter-state and foreign political relations. Keeping a positive relationship with the military officers of the Continental Army was equally important. When the French military came to assist the Americans, establishing a positive relationship with the French military became a key component to the success of the alliance. In fact, his efforts to build up the French alliance resulted in the American government moving away from any potential thought of reconciliation with Great Britain. This became especially important as Laurens received Conrad-Alexandre Gerard, the new French minister. At Laurens’ insistence, Congress immediately appointed a committee to prepare for the official reception of the emissary. ${ }^{282}$

Shortly after Gerard arrived in America, Laurens began a personal relationship with him as a means of furthering the alliance. Though the congressional committee discussed the proper honors and tributes to bestow on the ambassador, the president wanted to learn more about his mission to the United States by transcending political relationships and establishing a friendship with him. ${ }^{283}$ "He intimated to me his powers for appearing in the character of Minister Plenipotentiary, or more simply, a resident,” Laurens wrote. "The court of France probably could not have discovered a man in

\footnotetext{
280 HL to George Washington, July 10, 1778, Papers. Chesnutt, 14: 15.

281 HL to George Washington, July 11, 1778, Papers. Chesnutt, 14: 19. This request had been written by a committee of the Continental Congress, and forwarded by Laurens.

282 Ford, JCC,11: 688.

283 Ford, JCC, 11: 685.
} 
Europe so equal to the task," he continued, "as is Monsieur Gerard--a man of politeness, good breeding, and affability without troublesome ceremony."284

Laurens took the time to get to know Gerard, not only the parameters of his diplomatic mission but his personal motivations for supporting the American cause. It was Gerard's hope to be recognized as a full ambassador by the Congress since he had arrived from France with full powers from the king. Though Laurens informed Gerard that such a decision "awaited the determination of Congress," he advocated such a distinction be made. What had motivated Laurens to pursue this course was his concern over the interests of the United States among the powers of Europe. Congress was also concerned about the status of the American representatives in France and whether or not they held such a distinction. ${ }^{285}$

In his discussions with Gerard, Laurens learned the answer to a question that had perplexed him since his first months in Congress. When pressed about the disaffected French officers who had applied to Congress for military commission and had been rebuffed, Gerard said that he was aware of their complaints. However, realizing that not every individual who had applied for such a commission was worthy, Gerard reported that "Congress would never be troubled with petitions under his auspices." ${ }^{286}$ This answer settled a very pressing concern for Henry Laurens. Should Congress continue to promote foreign notables over qualified American soldiers, a serious problem would result. "Many of our American officers have abandoned their homes, all their domestic happiness, the education of their children, the improvement of their fortunes," Laurens

\footnotetext{
${ }^{284}$ HL to Rawlins Lowndes, July 15, 1778, Papers. Chesnutt, 14: 31-36.

285 Ibid, 14: 34.

286 Ibid, 14: 34.
} 
wrote to the Marquis de Lafayette, “....and have the mortification of being commanded by gentlemen who had held Lieutenancies in their native country, and who were promoted here after one battle.”287

Conrad-Alexandre Gerard, French Minister Plenipotentiary, was officially presented to the Continental Congress on August 6, 1778. After giving his official greeting on behalf of the king of France, Gerard pledged that France would not cease in its determination to end the war until the United States had been recognized by Great Britain as an independent nation. "His majesty hath hastened to send you a powerful assistance, which you owe only to his friendship,” Gerard announced, “to the sincere regard he has for every thing which relates to the advantage of the United States...”288 After concluding his remarks, the minister was officially introduced to the Congress. In his official welcome to the French representative, President Laurens commented that "had it rested solely with the most Christian King, not only the independence of these states would have been universally acknowledged, but their tranquility fully established.”289 “The virtuous citizens of America,” he continued, “can never forget his beneficent attention to their violated rights, nor cease to acknowledge the hand of a gracious Providence in raising them up so powerful and illustrious a friend.”290

By the middle of July, a de facto state of war existed between France and Great Britain. Laurens received news of this development from the American Commissioners in France, Benjamin Franklin and John Adams. With the naval assistance of the Count d'Estaing, the costal areas of the United States were given protection from the British

\footnotetext{
287 HL to the Marquis de Lafayette, July 18, 1778, Papers. Chesnutt, 14: 46.

288 Ford, JCC, 11: 754-756.

289 Ford, JCC, 11: 756-757.

290 Ibid, 11: 757.
} 
navy. However, Adams informed the president that the king of France had now ordered his ships of war to begin attacking English vessel and had given his official assent to privateers. The American Revolution had now entered a stage of total war between two of the most powerful nations on earth. "War is not declared," Adams wrote, "that is no manifesto had been published... but each nation is daily manufacturing materials for the other's manifesto, by open hostilities.”291 Adams also warned the president not to heed the peace overtures made by the British government as they were insulting to the national dignity of the nation. Laurens agreed on this point and had given every indication of resisting the attempts by the British peace commission to persuade Congress to accept their peace proposals. ${ }^{292}$

The incident that further strengthened Laurens’ resolve concerned the repeated attempts of the British peace commission to bribe members of Congress into supporting their proposals. On July 9, 1778, Congress had requested its members to bring forward “all letters received from any of the British peace commissioners or their agents, or from any subject of the king of Great Britain of a public nature.” This was an attempt by the majority of the members of Congress to determine just how far the peace commissioners would go in their attempt to break down the resolve of the government. Laurens had been opposed to this plan when originally considered in June of 1778, on the grounds that a person's private mail should not be considered by the eyes of the entire government. "I could not forbear offering some objections," he wrote to Washington, "it appeared to be a dangerous attempt to stretch the powers of Congress.”293 However, as news was received

\footnotetext{
291 John Adams to HL, July 27, 1778, Papers. Chesnutt, 14: 82.

292 Ibid, 14: 82-83.

293 HL to George Washington, Papers. Chesnutt, 13: 484-486.
} 
of clandestine offers to members of Congress from representatives of the crown, his resistance faded somewhat.

Though he still did not support the idea of an individual's private correspondence being submitted for public consumption, Laurens offered no resistance to the decision of the Congress. He explained his change of opinion in a letter to General Washington dated July 31, 1778. In this letter, the president charged the British peace commission with sabotaging any attempt at negotiations, "having by various means, attempted to bride Congress.” To Laurens, this information represented "the highest possible affront to the representatives of a virtuous, independent people," and further "rendered wholly unworthy of the further regard of Congress in their ambassadorial character."294 Laurens referred to a letter sent to Pennsylvania Delegate Joseph Reed from George Johnstone, a member of the British peace commission. This letter alluded to potential benefits for Reed if he were to support the commission and advocate a peace settlement between Great Britain and the United States. ${ }^{295}$ "I have for several days past," Laurens explained, "urged my friends to move Congress for a resolve that will hold no conference with such men."296

Laurens was concerned over the ramifications of such attempts to persuade members of Congress. Not only could such a discovery undermine the usefulness of the national assembly, but it could have diplomatic ramifications throughout Europe. "I am commonly tenacious of my own ideas," he wrote of his advocacy for the motion to break off contact with the commission, "but in the present, as in the former case, I feel as if I

\footnotetext{
294 HL to George Washington, July 31, 1778, Papers. Chesnutt, 14: 99-100.

295 Joseph Reed to HL, June 15, 1778, Papers. Chesnutt, 13: 462-464.

296 HL to George Washington, July 31, 1778, Papers. Chesnutt, 14: 100.
} 
clearly perceived many good effects which will be produced by a proper act on our part.”297 Though the motion eventually failed to gain support in the Congress, the attempts at bribery did not stop. When another delegate presented a similar letter to the president, Laurens immediately went to Congress and demanded that they take a more

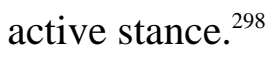

On August 11, 1778, Delegates Joseph Reed and Robert Morris of Pennsylvania laid before the Congress the private letters sent to them by George Johnstone. The letters were read publicly at the insistence of President Laurens and officially entered into the congressional record. ${ }^{299}$ To Reed, Johnstone indicated that "the man who can be instrumental in bringing us all to act once more in harmony,” would have the gratitude of the king and the thanks of the people of Great Britain. He had made a similar offer to Delegate Morris, offering him "honor and emolument" for guiding the Congress into accepting the British reconciliation plan. While both of the delegates had indicated that they were not swayed by such offers, they were obligated to present Johnstone’s letters to the Congress. After serious debate, the Congress resolved to have no more contact with George Johnstone respecting peace with Great Britain. While this resolution did not cut off communication with the entire commission, it did single Johnstone out for his attempted subversion of the Continental Congress. Laurens immediately sent a copy of the resolution to the peace commission, now located in New York. The letter that accompanied the resolution accused the commission of breach of faith and indicated that

\footnotetext{
Ibid, 14: 100.

298 Ford, JCC,11: 773.

299 Ford, JCC,11: 773-774.
} 
such actions would not be tolerated by the government of the United States. ${ }^{300}$

Throughout the remainder of his presidency, Laurens worked to solidify the French alliance, although at times he became frustrated with the demands of Count d'Estaing. Laurens also disagreed with the Marquis de Lafayette on the revitalization of a military expedition into Canada, a proposal that both Laurens and Washington realized would be futile. While their relationship did not suffer from this disagreement, Laurens became wary of the demands of the French with respect to the United States. Thinking of the future status of the nation among the powers of Europe, Laurens dedicated his energy to resisting the continual reliance on foreign loans, as they would increase debt in the United States. He was also concerned over the future of the United States once the war with Britain had concluded. What type nation would exist in the aftermath of the war, when American had relied on the assistance of powerful countries like France and Spain. These were the major issues that the president contended with throughout the remainder of his exhausting term as President of the Continental Congress.

While Laurens was the first member of Congress to rejoice at the signing of the treaty of alliance, he realized that it was not a perfect document. He withheld his public criticism of the treaty to foster an open and mutually beneficial relationship with France. Laurens was concerned over the annexation of Florida by Spain as compensation for their assistance in the war effort. While the treaty did not indicate that Spain would gain control of Florida in exchange for its military assistance, it was a possibility that Laurens had considered. "We have nothing new from Spain,” he wrote to New Jersey Governor William Livingston, “gentlemen not only smiled, but laughed at my ideas expressed

300 Ibid, 11: 775. 
while we were reading the treaty with France, that the Spaniard had his eye upon the Floridas...”301 After a conversation with Don Juan de Miralles, a Spanish observer living in York who apprised the Spanish government on the political developments in America, Laurens commented that he had "received strong confirmation of my suspicions." While dining with Don Juan, Laurens learned that Spain did have an interest in regaining control of Florida as a means of achieving a foothold on trade with the southern states. “This I really mean sir, as a secret,” Laurens wrote, “and if we keep it so, the discovery may be applied to good purposes when we come to treat in earnest.” As always, Laurens was thinking of the possible benefits of working out a settlement with Spain that would be separate from any agreement that would come through France. "I am afraid our present commissioners are not apprized,” Laurens concluded, “of the immense value to our whole union of St. Augustine and Bahama, and that too many of us here, view the possession in a light of partial benefit.”302

In late of August of 1778, the Marquis de Bretigney proposed an invasion into British held territory of East Florida, which Laurens brought before the Congress. The previous American expedition into the region in July of 1778 had been an abysmal failure. Laurens described the situation as an "unhappy circumstance” which "will add to the distress of Georgia, and increase her cries for relief.” The American forces had previously been routed and taken severe losses against the British battalions in this effort to free up the region from British control and relieve the embattled southern states. ${ }^{303}$ When the plan for an all out assault on the region was proposed by Bretigney, Laurens

\footnotetext{
301 HL to William Livingston, August 21, 1778, Papers. Chesnutt, 14: 195.

302 Ibid, 14: 196.

303 HL to John Houston, August 27, 1778, Papers, Volume Fourteen. Chesnutt, 237.
} 
was somewhat skeptical as to its potential for success.

Congress agreed to employ a military expedition against the British in East Florida under the command of Major General Benjamin Lincoln in November of $1778 .{ }^{304}$ This expedition was vital to the security of the southern states, particularly Georgia and South Carolina. To gather the necessary personnel for this expedition, Congress allotted land bounties for all those who joined the general until the area had been reduced and occupied by American forces. Realizing the vital importance of this campaign, not only to the safety of the southern states but to America's bargaining power in the region, Laurens advocated granting every soldier involved in the attack a portion of the land that was seized. Originally, the Congress had intended only to allot these land bounties to the commanding officers and their support staffs. However, Laurens knew that the citizen soldier who had enlisted in the regiment was important, and needed proper motivation to leave their homes and join Lincoln in Florida. ${ }^{305}$

While the command of the invasion force was bestowed on Lincoln, the Continental Army was augmented by the militia units from Georgia, Maryland, Virginia, and South Carolina. This required the cooperation of the various state executives, some of whom were understandably concerned about the defense of their own states. To his own home state, Laurens asked for immediate cooperation while at the same time insisting that it was not the position of Congress to imply that the state leadership had no control over their individual militias. ${ }^{306}$ Cooperation among the states was important to the success of this mission. Congress continued to debate the issue of the attack on East

\footnotetext{
304 HL to Richard Caswell, November 14, 1778, Papers, Volume Fourteen. Chesnutt, 486-487.

305 JCC, Volume Twelve. Ford, 949-951.

306 South Carolina Delegates to Rawlins Lowndes, November 14, 1778, Papers. Chesnutt, 14: 489.
} 
Florida through November of 1778 and into the first week of December, where it was decided that such a proposal would be futile and result in great injury to the southern states. $^{307}$

At the same time the Congress worked out the particulars of an invasion into East Florida, it was confronted with another ghost from its past. In September of 1778, General Horatio Gates and General Jacob Bayley submitted a report to General Washington outlining the potential for another military expedition into Canada. Washington subsequently submitted this report to the Congress, which approved of it in October of that same year. Congress ordered Laurens to write to Benjamin Franklin in France and to consult with the French government on the validity of the plan. Although at the time Laurens assumed that it was Lafayette who had revitalized the concept of an invasion into Canada, the Marquis had only supported the idea. However, when Congress ordered General Washington to begin outlining the supplies necessary for an invasion into Canada, both were certain that the idea originated with Lafayette. ${ }^{308}$

This resulted in a series of misunderstandings regarding the expedition.

Lieutenant Colonel John Laurens informed the president that the Marquis de Lafayette was desirous of introducing his plan for using French forces as a part of the Canadian expedition. Lafayette had informed Washington that Canada could not be taken solely by American forces, but would require a Frenchman at the head of the army to sway the hearts of the people. John Laurens further warned his father that allowing the French to have a foothold in Canada could cause problems for the United States in the future. John Laurens worried about the potential manipulation of trade by the French, should they gain

\footnotetext{
307 Ford, JCC, 12: 1184.

308 Ford, JCC, 12: 1042-1048.
} 
control of Canada. ${ }^{309}$ Washington privately confessed that France could use Canada as a means to gain a foothold on valuable trade with Indian nations and monopolize the fishing industry of Newfoundland. The president was also concerned over this possibility. ${ }^{310}$

As Washington prepared his report for the Congress, Laurens began to seriously reconsider the proposed attack. "I believe, and upon good ground,” he wrote, "the scheme for an expedition into Canada in concert with the army of France originated in the breast of Marquis de Lafayette...” While Laurens felt that this plan was created with "the purest motives," it was still a dangerous idea that was complicated "with eventual mischiefs.”311 What greatly concerned the president regarding a joint operation with France would be the financial straits it would put on the American government. Even if France were to assume the greater responsibility in the campaign, the American government would still need to rely on French loans. "I was one of the six unsuccessful opponents to the resolution for borrowing money from France," he added, "we have in this single article plunged the union into a vast amount of debt." Commenting on the example this would set for the United States abroad, Laurens predicted "imminent danger of dishonor and disgrace.”312 This represented a problem that Laurens had noticed from his first weeks as a member of the Continental Congress. If America were to rely too heavily on the assistance of foreign nations, it would soon place itself in a position where it would not be able to subsist alone. Furthermore, a dependence on foreign assistance would undermine the very concept of American liberty. "Every million livres you

\footnotetext{
309 John Laurens to HL, October 7, 1778, Papers. Chesnutt, 14: 392.

310 Washington to HL, November 14, 1778, Papers. Chesnutt, 14: 491-495.

311 HL to George Washington, November 20, 1778, Papers. Chesnutt, 14: 514.

312 Ibid, 14: 515.
} 
borrow," Laurens argued, "implies a pledge of your lands..." "If the prosecution of so extensive a project is from the present state of our army and funds impracticable," he concluded, “...I trust the Marquis will be satisfied with such reasonings in apology for our desisting from the pursuit of his favorite enterprise as our circumstances will dictate."313

In order to pay for this mission, Laurens predicted that the Congress would have to raise $\$ 20$ million in taxes for the coming year. "This heavy tax,” he confessed, "and the prospect of increasing impositions will show our constituents the necessity of consolidating our strength, as well as the impropriety and danger of new military enterprises." ${ }^{\text {314 }}$ Laurens forwarded the Commander-in-Chief's objections on the proposed invasion to the Congress, where it was considered by the Board of War. Adding his own objections on the grounds that such an endeavor would be costly and detrimental to the security of the nation, Laurens advocated that Congress cancel the planned invasion. After considerable debate, the second proposed invasion into Canada was cancelled by Congress in January of $1779 .{ }^{315}$ Laurens wrote to Lafayette explaining the government's decision. "Although the emancipation of Canada is a very desirable object," he assured the Marquis, “...considering the exhausted state of their resources, and the derangement of their finances, they conceive it very problematical whether they could make any solid impression in that quarter."${ }^{\text {316 }}$

With the abandonment of the extraneous invasion plans, Laurens was able to

\footnotetext{
313 Ibid, 14: 515-516.

314 Ibid, 14: 516.

315 Worthington C Ford, ed. Journals of the Continental Congress, Volume Thirteen: 1779-January 1April 22. (Washington: Government Printing Office, 1909), 13: 12-14.

316 Ford, JCC, 13: 14. Although Laurens resigned the presidency of Congress in December of 1778, he was still answering correspondence regarding decisions made while he held the chair.
} 
focus his attention on settling another past matter. "Mr. Deane is returned to Congress in pursuance of an order in the last winter," Laurens wrote to Rawlins Lowndes in July of 1778. ${ }^{317}$ The question over Silas Deane’s actions while serving as American Commissioner to France was of great concern for many within the Congress, including President Laurens. The state of affairs among the American representatives in France was becoming bothersome to the government and Deane's actions while in Paris had caused a great stir during Laurens' first months in Congress. ${ }^{318}$

Silas Deane had promised dozens of wealthy Frenchmen commissions in the Continental Army in exchange for their financial support. As the numerous French military figures crowded the halls of Congress in September of 1777, Laurens had noted the dangers of allowing these men commissions in the army over native born citizens of the states. ${ }^{319}$ Despite his recall, Deane did not actually return to the United States until well after the treaty of alliance with France had been signed. Commanded by Congress "to give, from his memory, a general account of his whole transactions in France," Deane began describing his transaction while in Paris on August 15, 1778. Regarding Deane’s testimony, Laurens wrote "we know too much, and yet I almost fear we know nothing of our affairs in Europe. ${ }^{» 32}$

While Gerard, Franklin, and even the French Foreign Minister, Charles Gravier de Vergennes, had all spoken highly of Deane, Laurens commented "I shall form no conclusion until I learn much more than has hitherto come to my knowledge.”321 While

\footnotetext{
317 HL to Rawlins Lowndes, July 15, 1778, Papers. Chesnutt, 14: 34.

318 Burnett, 360-361.

319 HL to John Lewis Geravis, September 5, 1777, Papers. Chesnutt, 11: 493.

320 HL to William Livingston, September 1, 1778, Papers. Chesnutt, 14: 258.

321 HL to Rawlins Lowndes, July 15, 1778, Papers. Chesnutt, 14: 35.
} 
there were some members of the Congress who had indeed formed their own conclusions on Silas Deane's action while in Paris, Henry Laurens endeavored to reserve his judgment--at least publicly. It was clear from his writings in November of 1777, that Laurens did not approve of Deane's methods. However, when Deane published an account of the supposed disputes among the commissioners in Paris in the December $5^{\text {th }}$ issue of The Pennsylvania Packet, his detractors in Congress became incensed. Addressing the "free and virtuous citizens of America," Deane attempted to take his case to the people. ${ }^{322}$ The result would forever sully Deane’s reputation among the members of the Continental Congress and be the root cause of Henry Laurens' resignation as its president.

Referring to Deane’s letter as an “unnecessary appeal,” Laurens sought to address the matter within the Congress. Deane's letter had "created anxieties in the minds of the good people of this city," and contained accusations "highly derogatory to the honor and interests of these United States.” Laurens, seeing Deane’s statements as “dishonorable,” urged the Congress to appoint a committee to review and critique his comments regarding the other commissioners in France and the defamatory statements made regarding the Continental Congress. Before the vote could be taken, a motion was made to adjourn Congress. Despite the president's objection, the house adjourned. ${ }^{323}$ Laurens took this action to be a sign of the divisions within the Congress. Though he had witnessed such conflicts between his colleagues before, they had never prevented his attempts to settle a matter. Insulted, Laurens sent out a hasty letter to General Washington that alluded to his next course of action. "You will be pleased sir," he wrote,

${ }^{322}$ Burnett, 363-364.

${ }^{323}$ HL to the Continental Congress, December 9, 1778, Papers. Chesnutt, 14: 573-577. 
"to direct your next dispatches to the President of Congress, who will not be the subscriber." Laurens promised the general that he would continue to assist him "in my private character,” as best he could. ${ }^{324}$

The records of the Continental Congress for December 9, 1778 indicate that before any business could be transacted, the president rose from his the chair and, after a brief address outlining his reasons, resigned his responsibilities. After serving the national assembly for over a year, Laurens returned to his seat as a delegate from South Carolina and allowed Congress to appoint someone else to contend with the tumultuous dictates of the national government. ${ }^{325}$ All evidence indicates that Henry Laurens took this action over a point of honor concerning Silas Deane's actions regarding the American delegation to France. There is no indication in the records of the Continental Congress that Laurens was asked to resign. Nor is there a record of an attempt to remove him from his position. He simply resigned. Aside from being exhausted at having served as president for slightly over a year, Laurens was offended by the quick dismissal of his objections over Silas Deane’s actions. For Laurens, it was a matter of personal honor. At this time in the United States, the concept of honor was held in the highest regard. Any infringement on a man's honor was a source of tension. ${ }^{326}$

On December 10, 1778, John Jay of New York was elected to fill the void created by Laurens' resignation. ${ }^{327}$ While Laurens' service as president was now over, he would not so quickly give up his national responsibilities. Rather, Laurens remained an active

\footnotetext{
${ }^{324}$ HL to George Washington, December 8, 1778, Papers. Chesnutt, 14: 571.

${ }^{325}$ Ford, JCC, 12: 1202. Deane would be dismissed by the Congress in August of 1779 and eventually he would return to Europe.

${ }^{326}$ Joanne B. Freeman, Affairs of Honor: National Politics in the New Republic. (New Haven: Yale University Press, 2001), xv-xvi.

${ }^{327}$ Ford, JCC, 12: 1206.
} 
member of the Continental Congress and continued to have a positive effect on the course of the American Revolution. 


\section{Chapter Five: A Life in Service}

Although Henry Laurens had been elected to another term as president of the Continental Congress in November of 1778, his anguish over the factions within Congress during the deposition of Silas Deane had compelled him to leave office barely one month later. Nonetheless, Laurens decided to remain in Congress as a representative of South Carolina. "I had never any ambition to sit in the chair of Congress," he explained to Samuel Huntingdon in December of 1778, "and when I had sat one complete year in it, I urged the house to make a better choice for filling it.” Laurens commented that it was "the unanimous voice then present requesting me to continue added to another circumstance overbalanced my determination to retire.” Holding his position and the status of Congress to be sacred in the affairs of the nation, Laurens explained that were he to continue as president amid the public statements made by Silas Deane he would be guilty of dishonoring the spirit of the position and the dignity of the national government itself. Deane had exposed the internal disputes between the American commissioners in Paris in widely published letter in December of 1778. This had caused another internal dispute within the government. Laurens' sense of honor regarding the factions within Congress compelled him to step aside rather than become embroiled in yet another partisan conflict that could destabilize the national government. Laurens felt that should Congress focus on national affairs and avoid internal disputes between its membership. ${ }^{328}$

Despite the circumstances that had brought about his resignation as president, Laurens was appointed by his colleagues to the Committee of Commerce on December

\footnotetext{
${ }^{328}$ HL to Samuel Huntington, December 11, 1778, The Papers of Henry Laurens, Volume Fifteen: December 11, 1778-August 31, 1778. David R Chesnutt, ed. (Columbia: University of South Carolina Press, 2000), 15: 1-2.
} 
14, 1778. The following week he was elected to chair that committee. ${ }^{329}$ It was during his service in this capacity that Laurens was able to convince the Congress to abandon the proposed Canada invasion on the grounds that there simply was not enough money for such an adventure. No longer bound to mediate the debates of the government, Laurens publicly stated his opinion on the issue and urged the assembly to drop the plan. His separation from the chair allowed him to express his view more forcefully than before. ${ }^{330}$ Throughout his next year in Congress, Laurens was appointed to committees on finance and military relations. He continued to serve the interests of the United States well and received the thanks of his colleagues numerous times with assignment to powerful committee posts. The remaining years of his life were dedicated to public service and continuing the growth of young nation. ${ }^{331}$

When the Congress finally agreed to compensate its presidents for their services, Laurens was deeply honored. Having spent a great deal of his own money to maintain lodging and provide a carriage for transportation, Laurens was grateful to be compensated. This decision affected President Jay more than Laurens, due to the fact that Congress also resolved to provide a suitable house and carriage for the current president. Laurens and his predecessors were asked to submit an account of all their expenses during their term of office. This resolution benefited the heirs of the late Peyton Randolph, as well as John Hancock and Henry Laurens. ${ }^{332}$ "I entreat you,” he wrote to President Jay on December 16, 1778, “to return my grateful acknowledgements to the

329 Ford, JCC, 12: 1216.

${ }^{330}$ Ford, JCC, 12: 1221.

331 Ford, JCC, 13: 25.

332 Ford, JCC, 12: 1222-1223. 
house, expressed in the enclosed paper."${ }^{{ }^{333}}$

Privately, though, Laurens confessed that the Congress had not come to this decisions easily. Those members of Congress who were offended by Laurens' resignation had argued over the wording of his official letter of thanks. In the end, the house unanimously resolved to thank Laurens for his services in the execution of public business. To Rawlins Lowndes, the former president expressed a sense of relief at being "released from the chair." Now, "my attention shall be bent to the investigation of the secret and commercial committee accounts...forsaking all thoughts of my private affairs for some time longer." ${ }^{334}$ This seemed to be a theme in Laurens’ private life, in that he deferred attending to his own affairs to serve the nation.

When Congress began an open debate on the prospects for attaining a loan from Holland, Laurens was at the forefront of the discussions. By this time, President Jay had been appointed Minster to Spain to secure financial and military assistance from that government. In yet another desperate bid for funds, Congress also resolved to appoint a commissioner to the Netherlands whose express purpose would be to negotiate a loan for the United States. On October 13, 1779, Laurens presented a letter from Lieutenant Colonel Jacob Gerhard Dirik outlining the potential for obtaining a loan from Holland. A committee, of which Laurens was a member, reviewed the letter and suggested that the Congress appoint a proper individual to negotiate the loan. Jonathan Trumbull, Sr. had forwarded Lieutenant Colonel Dirik’s letter to Henry Laurens and requested that he present it to Congress. On several occasions, the Congress refused to consider the letter on the basis that it did not contain important business. Laurens continued to advocate for

${ }^{333}$ HL to John Jay, December 16, 1778, Papers. Chesnutt, 15: 5.

${ }^{334}$ HL to Rawlins Lowndes, December 16, 1778, Papers. Chesnutt, 15: 6-8. 
its committal and finally placed the letter in the hands of President Samuel Huntingdon in October of $1779 .{ }^{335}$

The resolution empowering the American commissioner called for a man who possessed superior accounting skills and the ability to attain contacts in the mercantile field. Having spent most of his life in the merchant trade, Henry Laurens was the perfect man for the task. He was the first individual to have his name placed in nomination, and when the vote was taken he was appointed to the position. ${ }^{336}$ On October 30,1779, a special committee expanded Laurens' mandate and empowered him to negotiate a "treaty of amity and commerce with the United Provinces of the low countries." ${ }^{\text {337 }}$ On November 1, 1779, he was appointed the first American Commissioner to the United Provinces of the low countries. He was empowered to seek out a low interest loan and establish a diplomatic relationship with the Dutch. ${ }^{338}$

Laurens left the city of Philadelphia on November 9, 1779 and immediately set out for South Carolina. ${ }^{339}$ Arriving in Charles Town on December 10, 1779, Laurens was perplexed to find that none of his instructions from the Congress had arrived. He had no written mandate from the American government to pursue a loan, nor did he possess the treaty that had been written by the Committee on Foreign Affairs. Lacking a proper staff, and even an assistant, Laurens wrote to President Samuel Huntingdon. "I have not been furnished with the act for my appointment," he commented, "for the appointment of a secretary, with commission and instructions for negotiating a treaty of commerce with the

${ }^{335}$ HL to Jonathan Trumbull, sr., October 19, 1779, Papers. Chesnutt, 15: 189-192.

336 Election to Negotiate Dutch Loan, October 21,1779, Papers. Chesnutt, 15: 192.

337 Worthington C. Ford, ed. Journals of the Continental Congress, Volume Fifteen:1779-September 2, 1779-December 31, 1779. (Washington: Government Printing Office, 1909), 15: 1210-1211.

${ }^{338}$ Ford, JCC,15: 1232.

339 notation, Papers. Chesnutt, 15: 204. 
United States of the Netherlands...nor has the opportunity offered for my sailing to Europe.”340 Those ships that were available at Charles Town harbor were bound for France and could not transport the frustrated commissioner to his destination. Laurens was forced to seek his own method of transportation to the Netherlands. ${ }^{341}$

Even though the proper instruction outlining his diplomatic mission had failed to arrive in South Carolina, Laurens began to keep an account of his mission. The financial and personal records of this journey from Philadelphia to South Carolina are an accurate portrayal of what occurred during his voyage to the Netherlands. Even before he left the United States, Laurens had spent over \$13,315 transporting his belongings, personal papers, and shipping a supply of leather that he purchased in South Carolina for the board of war. ${ }^{342}$ In the time between his request for orders from the Continental Congress and his departure for the Netherlands, Laurens was able to return to the realm of regional politics, being elected to the South Carolina House of Representatives in January of 1780. It was during this service that Henry Laurens introduced a progressive proposal that had been advocated by John Laurens, when Henry Laurens was president of Congress.

Though he only served in the House of Representatives for two full days, Laurens was able to introduce a bill that provided for the enlistment of free blacks in the South Carolina militia. After the proposal was rewritten, a committee of the house agreed that free blacks would be a necessary addition for the South Carolina militia. The house approved of the plan and further ordered that commissioners be appointed to enlist 1,000

\footnotetext{
340 HL to Samuel Huntingdon, December 20, 1779, Papers. Chesnutt, 15: 217-218.

341 Ibid, 15: 219.

342 Account with the United States, January 20-July 24, 1780, Papers. Chesnutt, 15: 224-225.
} 
freed blacks as a source of labor to assist with the defense of the state. Though they would not be directly involved in the fighting, these laborers were to receive compensation for their efforts. ${ }^{343}$ This proposal represented a serious ideological victory for John Laurens, who had encouraged his father to support a similar proposal during his presidency. Beginning in 1778, John Laurens had requested that the then President Laurens propose the enlistment of a regiment of black soldiers in the Continental Army ${ }^{344}$ Though the elder Laurens did not wish to discourage his son, he realized that such a bold plan would meet with heavy resistance among the members of Congress. He further argued that to conscript a regiment of slaves and free blacks into a military unit was no better than slavery itself. ${ }^{345}$ He changed his mind after repeated entreaties from John Laurens, when Henry finally saw the opportunity to advance this idea.

When a British fleet arrived off the coast of South Carolina in February of 1780, Laurens informed the Committee on Foreign Affairs that he would set out on his own to North Carolina to attain passage on a ship bound for Europe. "In the meantime," he added, "I shall omit no opportunity of acquainting you with my circumstances.”346 This was a reference to the lack of communication from the Congress regarding his mission. Once more, Laurens was about to embark on a journey that would be, at least for him, part improvisation.

In April of 1780, Laurens went to Wilmington, North Carolina to board a European-bound vessel, but found it difficult to obtain passage. Every available ship was being used to either supply the states or fight off the British. The French vessels were

\footnotetext{
343 notation, Papers. Chesnutt, 15: 232-233.

344 John Laurens to HL, January 14, 1778, Papers. Chesnutt, 12: 305.

345 HL to John Laurens, January 22, 1778, Papers. Chesnutt, 12: 328.

346 HL to the Committee for Foreign Affairs, February 14, 1780, Papers. Chesnutt, 15: 235-236.
} 
constantly engaged in maneuvers against the British, which delayed Laurens’ diplomatic mission. ${ }^{347}$

As Charles Town was bombarded by British warships, Laurens learned that the South Carolina government was in flight to Camden. When the city surrendered on May 12, 1780, over 2,600 American prisoners were taken by the British, including Lieutenant Colonel John Laurens. “Upon my honor,” Laurens wrote to the South Carolina delegation in Congress, "I have not shed one tear, from any consideration respecting my son or myself.” "Let not this damping picture incline us to despondency,” he continued, "but, impel us to act with more wisdom, more vigor for the relief of our unhappy fellow citizens, the recovery of our country, and the establishment of our independence.” ${ }^{348}$ As he received reports from Charles Town outlining the devastation brought to the city by the American surrender, Laurens became more aware of the importance of attaining a loan from the Dutch. A letter from John Laurens, now in captivity, reiterated this concern and fell heavily upon the elder Laurens. ${ }^{349}$

In July of 1780, Laurens finally received the official sanction of the Continental Congress to proceed on his mission to the Netherlands. Having personally returned to Philadelphia to determine what had held the official response from the Congress for so long, Laurens began his journey to the Netherlands in August of 1780 aboard the Mercury. ${ }^{350}$ His personal journal, kept throughout the next two years, contains detailed notes on the voyage.

${ }^{347}$ HL to Abner Ash, April 14, 1780, Papers. Chesnutt, 15: 281-282.

${ }^{348}$ HL to South Carolina Delegates in Congress, May 14, 1780, Papers. Chesnutt, 15: 293-296.

349 John Laurens to HL, May 25, 1780, Papers. Chesnutt, 15: 300. John Laurens was paroled by the British shortly after his capture on the condition that he remain in Pennsylvania. He traveled with his father until the Mercury reached Port Penn.

350 Board of Admiralty to HL, August 11, 1780, Papers. Chesnutt, 15: 329-330. 
In his trunk, Henry Laurens carried an "unauthenticated” copy of the proposed treaty between the United Provinces and the United States of America. Angered at the fact that Congress had not given him the authentic treaty to be signed, Laurens "threw it into a trunk" containing documents that he intended to go over at a later date. ${ }^{351}$ On September 3, 1780, the Mercury was stopped by the British frigate Vestal under the command of Captain George Keppel. "Captain Keppel received me on board in a stile humane and polite,” Laurens wrote, “I presented my sword and purse to him, he desired me to keep both.” Henry Laurens was now prisoner of the British. ${ }^{352}$

In his journal, Laurens details his efforts to dispose of the treaty and his personal papers so they would not fall into the hands of his captors. The documents were safely deposited in a "long bag” and thrown overboard by Laurens' secretary, Major Moses Young. While the bag was heavy enough to sink, an air pocket inside it prevented this from occurring. A sailor on the Vestal pulled the bag from the sea and the treaty was recovered. Laurens commented that Captain Keppel performed his duties well and was worthy of praise for the respectful way he treated his prisoner. "I shall now be sent to England," Laurens wrote, "where I shall be of more real service to my own country than I could possibly be in any other part of Europe.” Despite the fact that his diplomatic mission to the Netherlands was, under his present circumstances, a total failure, Lauren maintained a positive attitude. ${ }^{353}$

Transferred to the British vessel Fairy, Laurens arrived in England on September 19, 1780. Placed under the guard of a young Lieutenant named Norris, Laurens was

\footnotetext{
351 Journal of HL, August 25, 1780, Papers. Chesnutt, 15: 332.

352 Journal of HL, September 3, 1780, Papers. Chesnutt, 15: 333-334.

353 Ibid, 15: 334-335.
} 
taken to London. When Lieutenant Norris was visiting friends in Exeter for several days, Laurens had the opportunity to escape his captor and disappear into the English countryside. He chose to remain and face the ordeal that was coming to him. "I feel no inclination to escape,” he replied to William Knox, undersecretary of state for the American colonies, who actually encouraged Laurens to slip away while the Lieutenant was remiss in his duties. ${ }^{354}$ Arriving in London on October 6, 1780, Laurens was escorted under heavy guard to White Hall to meet with members of the king's privy council. After his interview, Laurens was confined to the Tower of London on the charge of suspicion of high treason against the crown. ${ }^{355}$ Locked up at night, and under the custody of two guards, Henry Laurens was denied the right to write or receive correspondence. When a bystander commented on the unfortunate situation that Laurens was reduced to and that it was likely that he would die in the tower, Laurens responded, "I shall not leave a bone with you.”356

Henry Laurens spent fifteen months as a prisoner in the Tower of London. In that time he was subjected to several attacks of gout and suffered from numerous health ailments. ${ }^{357}$ When asked by an old friend named Oswald to apologize to the British government for his actions during the revolution, Laurens responded “I will never subscribe to my own infamy and to the dishonor of my children.” Even though Oswald had assured Laurens that he would be pardoned for his crimes against the crown if he could offer some sign of contrition, Laurens refused to assent. In his mind, he had

\footnotetext{
354 Ibid, 15: 339.

355 Ibid, 15: 340-341.

356 Ibid, 15: 341-343.

357 Wallace, 365.
} 
nothing to be sorry for. ${ }^{358}$

Throughout every interview with members of the privy council and representatives from the British government, Laurens refused to denounce the American cause. On December 31, 1781, Laurens was transported to Searjant's Inn for a hearing on his possible release from the tower. When asked to swear an oath on "our sovereign Lord, the King,” Laurens exclaimed “not my sovereign!”359 By this time, General Charles Cornwallis, second in command of the British army in North America, had surrendered to the Continental Army at Yorktown. ${ }^{360}$ The fighting was over, the United States and their allies had won the war for independence.

Laurens was released from the Tower of London in January of 1781, officially exchanged for Lord Cornwallis. After recuperating in Bath, England, Laurens was informed that Congress had appointed him as one of America’s commissioners to the peace conference in Paris. After over a year as a prisoner of the British, Laurens was now empowered to settle the terms of their surrender and attain official recognition of American independence. ${ }^{361}$ Though uncertain of the legality of his status, Laurens met with John Adams in Holland on April 14, 1782 to discuss the conditions for negotiating with Great Britain. Both men agreed that no negotiations would take place unless America was recognized by Great Britain as a sovereign nation. ${ }^{362}$ Back in England, Laurens worked to impress this upon the earl of Shelburne, who was a member of Prime Minister Rockingham's cabinet. In a private meeting with the earl, Laurens insisted that

\footnotetext{
358 Journal of HL, March 7, 1781, Papers. Chesnutt, 15: 357-358.

359 Journal of HL, December 31, 1781, Papers. Chesnutt, 15: 396.

360 Burnett, 523. The date for Lord Cornwallis' surrender is October 19, 1781.

361 Benjamin Franklin to HL, April 22, 1782, Papers. Chesnutt, 15: 482-483. Laurens had actually been appointed to this commission in June of 1781, while still a prisoner in the Tower of London.

${ }^{362}$ Memorandum on Conversation with John Adams, April 14, 1782, Papers. Chesnutt, 15: 486-488.

Adams had been appointed to replace Laurens as American commissioner to the Netherlands.
} 
the United States be recognized as an independent nation and that their rights be secured for the future. ${ }^{363}$

Devastating news and personal hardship seem to be integral factors in the life of Henry Laurens. On August 27, 1782, Lieutenant Colonel John Laurens was killed fighting a contingent of British troops at Chehaw Neck, South Carolina. ${ }^{364}$ While resting at Bath, Laurens received news of his son's death through John Adams. "I feel for you, more than I can or ought express," Adams wrote, “our country has lost its most promising character." ${ }^{365}$ Aware of the fact that America was in need of his voice, Laurens responded to Adams that he would comply with the wishes of Congress and attend the peace conference. “Thank God,” he concluded, "I had a son who dared die in defense of his country.” His emotional wound was deep, the deepest he had felt in many years, but Laurens was dedicated to the cause of independence. With the end of the war now assured and the looming prospect of peace, he could not delay his departure any longer. ${ }^{366}$ Once more, his private affairs would have to wait.

Frustrated at the fact that no official settlement of the war between the United States and Great Britain had yet to be reached, Laurens set out for Paris in December of 1782. He had spent the last year working with the British government in London to try and reach a settlement that immediately recognized the sovereign status of the United States. Knowing the ministers at While Hall would communicate their terms with the British representatives in Paris, Laurens felt his advocacy would make a considerable

\footnotetext{
363 Memorandum on Conversation with Lord Shelburne, April 24, 1782, Papers. Chesnutt, 15: 491-493.

${ }^{364}$ Massey, 226-227.

365 John Adams to HL, November 6, 1782, The Papers of Henry Laurens, Volume Sixteen: September 1, 1782-December 17, 1782. David R. Chesnutt and C. James Taylor, eds., (Columbia: University of South Carolina Press, 2003), 16: 52-53.

${ }^{366}$ HL to John Adams, November 12, 1782, Papers. Chesnutt, 16: 55.
} 
difference. In this capacity he acted as a point of contact for the American

representatives. He used his time in London to serve as the rear guard for the American negotiations in Paris. ${ }^{367}$

When the preliminary articles of peace were accepted by all parties in December of 1782, Laurens apprised the South Carolina delegation in Congress of the state of affairs. “The treaty,” Laurens wrote to John Lewis Gervais, “...will give general satisfaction on our side of the water and prove to be the ground work for our future happiness. ${ }^{{ }^{368}}$ Despite a few quarrels among the peace delegates over compensation for property losses, the definitive peace treaty concluding the American Revolution was signed on September 3, $1783 .{ }^{369}$

When he returned to Philadelphia from Europe in the summer of 1784, Laurens reported directly to the Continental Congress. After giving his report, Laurens began the long trip to his home in South Carolina. After serving the nation since 1777, Laurens now looked forward to a life of quiet retirement in the presence of his family and friends. ${ }^{370}$ Though he would endeavor to avoid holding political office throughout the remainder of his life, Henry Laurens remained active in the public world of American political thought. The citizens of South Carolina expressed their gratitude to Henry Laurens by naming one of the state's seven new judicial districts after him. He was once more elected to the state legislature in 1785 , but declined to serve due to personal reasons. When urged to seek the office of Governor of South Carolina, he also refused. "I am now what I had not been for thirty proceeding years..." he commented on his

\footnotetext{
${ }^{367}$ HL to William Manning, December 4, 1782, Papers. Chesnutt, 16: 66-67.

${ }^{368}$ HL to John Lewis Gervais, December 14, 1782, Papers. Chesnutt, 16: 73.

${ }^{369}$ Christopher Hibbert. Redcoats and Rebels: The American Revolution Through British Eyes. (New York: Avon Books, 1990), 337.
} 
return to civilian life, “...'tis happy for us when we know where to stop.”371

Laurens was ready to stop and settle down for the first time since the late 1750s, when he had entered public service. His financial affairs were in a state of near ruin as a result of the war for independence and his absence from Mepkin. His plantations in Georgia had been seized by the British and put up for public auction in late 1787. Although this was not a phenomenon totally unique to Henry Laurens, the effect that this financial ruin had on his personal well being was just as draining as his presidential services ten years earlier. ${ }^{372}$

Throughout the next five years, Laurens remained a well respected public figure in South Carolina. Having experienced the inherent flaws of the Articles of Confederation, Laurens became the proponent of a stronger union of the states. Though he had been elected as one of South Carolina's delegates to the Constitutional Convention in 1787, Laurens reported that he was "incapable of any arduous business." While he was honored to once more be chosen by his peers to represent the interests of his state, he maintained that it would not possible for him to travel to Philadelphia. ${ }^{373}$ Though he could not join his colleagues in Philadelphia, Laurens nevertheless expressed his opinions to those who updated him on the progress of the convention. Philadelphia merchant William Bell was Laurens' source of information during the debates. While Bell was not a member of the Constitutional Convention, he was an observer of the situation and the conduct through which Henry Laurens was able to publicly express his feelings on the proposed Constitution.

\footnotetext{
370 Wallace, 420-421.

${ }^{371}$ HL to William Bell, February 7, 1785, Papers. Chesnutt, 16: 536.

372 HL to Edward Bridgen, January 8, 1787, Papers. Chesnutt, 16:686-689.

373 HL to William Bell, April 28, 1787, Papers. Chesnutt, 16: 709.
} 
In a series of letters to Bell, Laurens voiced his concerns over the powers of the office of President of the United States. "I have one capital objection," he wrote in October of 1787, "they have given the intended President no coercive power in the passing of laws.” Laurens further argued that if the convention were going to create such an office, "they should either have given him power, or entirely have omitted his name on that subject.” ${ }^{374}$ Bell published the letter in the next issue of the Pennsylvania Gazette without Laurens` knowledge. The letter was subsequently reprinted in several other midAtlantic news papers throughout October and November of 1787. The subsequent articles credited Laurens with advocating the adoption of the proposed Constitution, provided that the convention amend its guidelines for the powers of the President. Not wishing to overtly influence the delegates who were attending the convention, Laurens responded to Bell's actions. “...I acknowledge the system is an "improvement," upon the present confederation,” Laurens wrote, “...in a work of such vast importance, ’tis our duty to proceed with cautious and wise deliberation." ${ }^{375}$

Laurens did get the opportunity to express his opinion on the final Constitution once it had been accepted by the convention in Philadelphia. Elected as a delegate to South Carolina's ratification convention, Laurens returned to Charles Town in April of 1788. The South Carolina ratification convention met from April 17 until May 28, 1788. When the vote was totaled, the new Constitution of the United States was approved by a vote of 149 to 73 . Henry Laurens apparently approved of the revisions made by the delegates in Philadelphia and voted in favor of the new document. ${ }^{376}$

${ }^{374}$ HL to William Bell, October 11, 1787, Papers. Chesnutt, 16: 738.

${ }^{375}$ HL to William Bell, November 19, 1787, Papers. Chesnutt, 16: 744-746.

${ }^{376}$ Notes on the Ratification Convention, April 17-May28, 1788, Papers. Chesnutt, 16: 751. 
When George Washington was a candidate for President of the United States, in the first election for that office, Henry Laurens was one of the electors from the state of South Carolina. ${ }^{377}$ Having expressed his displeasure at the inherent weakness of the presidency in the early drafts of the Constitution, Laurens was now satisfied that the new system would provide the firm leadership that the nation required. Having experienced the limited authority of being President of Congress, Laurens recognized how much more effective a federal government would.

Retiring once more to Mepkin, Laurens surrounded himself with his children and their families. On December 8, 1792, the man who never sought political distinction yet had found his life closely connected with the fortunes of the young American nation died at the age of $68 .{ }^{378}$ In accordance with his will, Laurens was cremated. ${ }^{379}$

History has underestimated the effect that Henry Laurens had on the course of the American Revolution and the success of the fragile young republic during its most tumultuous experience. His interest in American rights was not confined to the sphere of his home in South Carolina. When called to national service, he embraced his responsibility with stern determination despite any personal misgivings that he had entertained. Laurens grew from a proponent of reconciliation into America's fiercest advocate. His gradual evolution from reconciliation into sovereignty was the direct result of his term as President of the Continental Congress. With each crisis he encountered, Laurens became more determined to lead America through the stormy seas of revolution. For slightly over one year, Henry Laurens was the political head of a developing

377 Electoral Vote, February 4, 1789, Papers. Chesnutt, 16: 756.

${ }^{378}$ Gazette newspaper, December 11, 1792, Papers. Chesnutt, 16: 791.

379 Will of HL, November 1, 1792, Papers. Chesnutt, 16: 795-801. 
nation. There were no set criterion on how the President of Congress was supposed to act or what powers he possessed. Like his predecessors, Laurens had to improvise his role. Rather than taking the perspective of an observer, he became an active participant in the functions of the American government and used his position to put forward those ideas and political concepts that he felt were most essential to the success of the revolution. At times, Laurens simply underscored the congressional resolutions that he thought were most important. During more perplexing issues, he would take bold steps to find a solution. His correspondence is the single greatest body of evidence to support this conclusion.

As his fellow delegates became distracted from their public duties and abandoned the Congress, Laurens was left with responsibility of moderating a waning government. Calling the remaining delegates into extra sessions, Laurens began a public correspondence that urged the individual states to replenish their congressional delegations. The orders had come from Congress, but the sentiments were his own. At a time when the nation was in need of dedicated leaders, Laurens came to the forefront and through his encouragement was able to hold the legislature together.

When a dispute between George Washington and General Thomas Conway threatened the stability of the Continental Army, Laurens was faced with a potentially dangerous political conflict. The Conway-Washington dispute represented a very real threat to the continuance of the American cause. Furthermore, any conspiracy to undermine the authority of General Washington was also a direct threat to the French alliance. Receiving information from his son, Laurens endeavored to prevent knowledge of this dispute from reaching the public. He also worked to calm the tensions between 
the two generals before others had the opportunity to take sides. When all the facts had been presented, Laurens determined that General Conway was the root cause of the internal conflict. Laurens publicly supported General Washington and curtailed any potential movements to undermine his command of the Continental Army.

Moreover, Washington's friendship with the Marquis de Lafayette presented a potentially damaging diplomatic quagmire. Angered at the insubordinate attitude of General Conway, Lafayette demanded that the government take decisive disciplinary action on the matter. Laurens feared that Lafayette would withdraw his support of the revolution if the American government did not support the Commander-in-Chief. Were Lafayette to resign his commission in the army and return to France, the financial and military support needed by the Americans would evaporate. Fortunately, Laurens was able to maintain a firm grip on the conspiracies that perplexed the American military during the winter of 1777-1778. The French alliance was maintained, and Lafayette gained a greater respect for Laurens, thanks to his public support of Washington amid the criticism of his subalterns.

Diplomacy was at the center of Laurens national service. His term as president was an effort to reach out to the essential players in the American Revolution. When the states faltered in their representations, Laurens evoked the revolutionary spirit of the individual state governments and encouraged them to take a more active stance in the affairs of the national government. It wasn't just their own state that they were fighting for, it was the liberty of a new nation.

To prevent the dissolution of the military, Laurens urged an atmosphere of cooperation between the state militia leaders and the regional commanders of the 
Continental Army. To maintain the military and commercial alliance with the French, Laurens urged the government to ignore any attempts by the British to generate a rift between America and France. He further argued that there could be no discussion about the end of hostilities without England's public acknowledgement of the sovereign status of the United States. His dealings with the Carlisle peace commission represent his determination to see the thirteen colonies recognized as free and independent states. Throughout his public interaction with representatives of the British government, the man who had once espoused reconciliation with Great Britain came out as America's most fervent advocate.

Henry Laurens maintained the delicate balance between the interests of the individual states and the nation as a whole throughout his presidency. In his public service he was both a diplomat and a crisis manager. His service to the American Revolution cannot be overlooked. Without his determination and tireless efforts, the revolution would have descended into chaos. Without his sometimes genuflecting relationship with the French, the United States would have lost its strongest ally in its quest for independence. Laurens took on the burden of leadership in a position that contained no definition of authority. The concept of a chief executive was alien to the United States that Henry Laurens served. However, necessity demanded a firm leader in the midst of the winter of 1777-1778, and Henry Laurens fulfilled that demand admirably. 


\section{Bibliography}

\section{$\underline{\text { Primary Sources }}$}

Chesnutt, David R., ed. The Papers of Henry Laurens, Seven Volumes. Columbia: University of South Carolina Press, 1985, 1988, 1990, 1992, 1994, 2000, 2003.

Fitzpatrick, John C., ed. The Writings of George Washington, Three Volumes. Washington D.C.: United States Printing Office, 1934.

Ford, Worthington C., ed. The Journals of the Continental Congress: 1774-1789. Volumes 8-13. Washington: Library of Congress, 1904-1937.

Hamer, Philip M., ed. The Papers of Henry Laurens, Two Volumes. Columbia: University of South Carolina Press, 1968, 1972.

Rogers, George C., ed. The Papers of Henry Laurens, Five Volumes. Columbia: University of South Carolina Press, 1974, 1976, 1978, 1979, 1980.

\section{$\underline{\text { Secondary Sources }}$}

Boorstin, Daniel J., ed. The Birth of the Republic: 1763-89. Chicago: The University of Chicago Press, 1977.

Brown, Richard D. Major Problems in the Era of the American Revolution, 1760-1791. Boston: Houghton Mifflin Company, 2000.

Burnett, Edmund Cody. The Continental Congress. New York: The MacMillan Company, 1941.

Butler, Jon. Becoming American: The Revolution Before 1776. Cambridge: Harvard University Press, 2000.

Davis, Joseph L. Sectionalism in American Politics: 1747-1787. Madison: The University of Wisconsin, 1977.

Dickerson, Oliver M. The Navigation Acts and the American Revolution. New York: Octagon Books, 1978.

Ellis, Joseph J. Founding Brothers: The Revolutionary Generation. New York: Vintage Book, 2000.

Ferling, John. Setting the World Ablaze: Washington, Adams, Jefferson, and the American Revolution. Oxford: Oxford University Press, 2000. 
Freeman, Joanne B. Affairs of Honor: National Politics in the New Republic. New Haven: Yale University Press, 2001.

Greene, Jack P. The Quest for Power: The Lower Houses of Assembly in the Southern Royal Colonies, 1689-1776. Chapel Hill: The University of North Carolina Press, 1963.

Lancaster, Bruce. The American Revolution. Boston: Houghton Mifflin Company, 1971.

Langguth, A.J. Patriots: The Men Who Started the Revolution. New York: Simon and Schuster, 1988.

Leach, Douglass Edward. Roots of Conflict: British Armed Forces and Colonial Americans, 1677-1763. Chapel Hill: The University of North Carolina Press, 1986.

Massey, Gregory D. John Laurens and the American Revolution. Columbia: University of South Carolina Press, 2000.

McDonough, Daniel J. Christopher Gadsden and Henry Laurens: The Parallel Lives of Two American Patriots. Sellinsgrove: Susquehanna University Press, 2000.

Morgan, Edmund S. The Birth of the Republic: 1763-89. Chicago: The University of Chicago Press, 1956.

Morris, Richard B. Witness at the Creation: Hamilton, Madison, Jay, and the Constitution. New York: Holt, Rinehart and Winston, 1985.

Nevins, Alan. The American States During and After the Revolution. New York: The MacMillan Company, 1927.

Rossie, Jonathan Gregory. The Politics of Command in the American Revolution. Syracuse: Syracuse University Press, 1975.

Stokesbury, James L. A Short History of the American Revolution. New York: William Morrow, 1991.

Wallace, David Duncan. The Life of Henry Laurens. New York: Russell and Russell, 1915.

Wheeler, Richard. Voices of 1776: The Story of the American Revolution in the Words of Those Who Were There. New York: Penguin Books, 1991. 